\title{
The Fabric of Canada
}

\author{
Catherine Mathias* \\ Mathias Heritage Publishing, Canada
}

Submission: May 21, 2018; Published: August 15, 2018

*Corresponding author: Catherine Mathias, Mathias Heritage Publishing, Canada, Tel: 705-324-1823; Email: cmathias@mun.ca

Keywords: Cottage industry; Fabric; Surgeon; Blacksmiths; Fishermen; Boat masters; Husbandman; Quarryman; Women; Children; Servants; Harbour; Artifacts; Archaeology; Suffolk cloths; Flannels

\section{Introduction}

Of Making Cloth with Sheeps Wool Smallest and smoothest pile grow on the pole. The coarsest about the Tayle. The shortest on ye head and on some parts of ye belly. The longest on ye flanks. Being sorted to wash it in ordinary water, in soape, then its dyed in rase otherwise it is wrought while into cloth and the cloth dyed afterwards [1].

The textile industry changed in the $17^{\text {th }}$ century from one which depended on the domestic "cottage industry" for supplies to one which became reliant on mass-production and a cosmopolitan trade network in which North America became a consumer [2]. The rise of the warehouseman and the factory meant that the small markets and halls used when goods were produced in homes by families were abandoned for inns and warehouses [3]. The introduction of the New Draperies, which were manufactured with different looms, used worsted yarns, which produced finer fabric, with a higher thread count [4]. The quotation above reflects upon the domestic clothing industry of the 1660s in England, which, with the introduction of the New Draperies and ready-mades, would by the 18th century be forever changed [5]. Clothing would become more disposable as cheaper methods for weaving, knitting, dyeing and constructing would become available. Because a society's costume helps to define groups by country, region and status, changes in its production impacted society in other ways. As a consumable, this commodity, in terms of wool production, was England's major export from the Medieval period through to early modern period [6]. This commodity afforded England the financial capability to explore other geographic regions and allowed it to become one of the largest Empires of the Modern Period. The fabric of a nation, however, is not based solely on its economic wealth. Once the fibre is woven into cloth, dyed, and constructed into a garment, it becomes an item which can define a region and status. Personal items such as costume are adapted to fit the needs of smaller groups, such as colonizing peoples, within a nation.

The textile industry and costume construction and style influenced $17^{\text {th }}$-century society, from being a major industry to contributing to the stratification of social structure and the notion that the "clothes make the man". We can therefore garner information about the past by examining archaeological textile remains, extant textiles, and textile images portrayed in printed images.

Many questions arise from the research previously described. The examination of the Ferryland textile collection has aided understanding of English colonial life in the $17^{\text {th }}$ century. This has been made possible by employing a variety of techniques including the archaeological and analytical sciences, the results of which have been described in previous chapters. The following discussion will combine information gleaned from this analysis. The importance of the small finds excavated from an undisturbed $17^{\text {th }}$-century privy has shed light on the many changes that occurred in this period on the north eastern American continent.

\section{The Ferryland Collection}

The bulk of the textile remains that comprise the Ferryland textile assemblage were excavated from a privy, in use from the 1621 , to the early 1670 s, when it was capped following the Dutch raid in 1673. Hundreds of square fragments of cloth excavated from the privy, were used for hygiene purposes, but by whom? The scraps of silk trim were likely scraps from a tailor, possibly William Sharpus or a second tailor who replaced him, but from which household? Captain Wynne arrived in Ferryland in 1621 with a dozen settlers [7]. Twenty more settlers arrived 
in 1622 including a tailor, a surgeon, blacksmiths, fishermen, boat masters, a husbandman, a quarryman, women, children and servants [8].

At this point there is mention of a kitchen, a parlour, a henhouse, defensive works, two tenements, salt works and a forge having been built, and with a brew house under construction [9]. Calvert visited the colony in 1627 and in 1628 he brought his family and an additional 40 settlers to Ferryland. The following year he quit the colony, moved his family back to England and went south to explore the Chesapeake area [10]. The Kirke's arrived in Ferryland in 1638 bringing some 100 settlers. They continued to build (for example the Kirke houses at Area F), and profit from the rich fishery [11]. Captain Wynne, who directed the initial building phase including the warehouse, seawall and privy of Area C, made his buildings to last, which is in part why they exist today. Although not directly referenced to in any of Wynne's letters, one of his letters dated 1621, alludes to the construction of the "Harbour" [12]. This reference indicates that the privy, which was part of the seawall construction, may have been available for use as early as 1621 . Wynne may well have been one of the first to use the privy. As Governor of this colony (and an employee of the East India Company) he could likely have afforded the luxury of clouts for the privy.

To date, the Mansion House, Calvert's residence, has not been found. No privy is mentioned in Wynne's descriptions of the Mansion House. We think, therefore, that Calvert also likely made use of the privy. Chamber pots, though available at the time, have not been found in any quantity among the ceramic remains at Ferryland. It is therefore possible that all of the gentry used the waterfront privy. Given its public location, it is possible that was used by gentry-class men who did business with incoming and outgoing ships. It may also have been used by gentle women, such as Lady Kirke, who, with the help of her sons, ran her husband's business from 1651 until her death sometime in the 1670s [13]. One thing that is certain is that this privy was associated with a work area, rather than a domestic structure. The privy was therefore likely used by all involved in the fishery from those who fished, to those who sold the final product. In terms of the textile remains left in the privy, the difference may have been between those of a gentry sort had clouts to use and the fishermen who did not. This could explain the high-quality wool fragments used for hygiene purposes. The tailor's scraps of silk cloth and trim, unsuited to hygiene purposes, may have been deposited in the privy as a deterrent to reuse by those of a lower standing. It is almost certain that a tailor resided or worked near the privy, or that his place of work drained into the privy.

\section{The Ferryland Archaeology Site}

Excavations and analysis have been completed for Areas A, B, C, and D (Figures 1-4). The excavations of Areas F, and G are on-going, and analysis is still being conducted. Of interest here are the domestic structures, as they would have the highest potential for costume-related artifacts. Nixon and Crompton reported on houses of the middling sort in Areas B and D, respectively [14]. Neither household held numerous costume remains. This is in part because of burial environments unsuited to the preservation of textiles. Therefore, metal costume-related artifacts comprise the assemblages. In Area D, however, one textile fragment was found, CgAf-2:78983, three button holes with silver metal threads. These appear to have been from a coat of the late $17^{\text {th }}$ century. They had been cut out of a garment and represent the potential reuse of the metal threads. Other items include cuff-links, CgAf-2:80876, from Area D and a shoe buckle from Area B, CgAf-2:145219 Event 145. The Area B buckle is a rectangular shape with a drilled frame for a separate spindle and dates from 1690-1720 [15]. The costume remains from Area $\mathrm{F}$ are also dominated by metal artifacts because of its burial environment and far outnumber those of Areas B and D. This agrees with ceramic data which clearly shows the Area F house, or Kirke house, to be of a much higher status than those of Areas B or D [16].
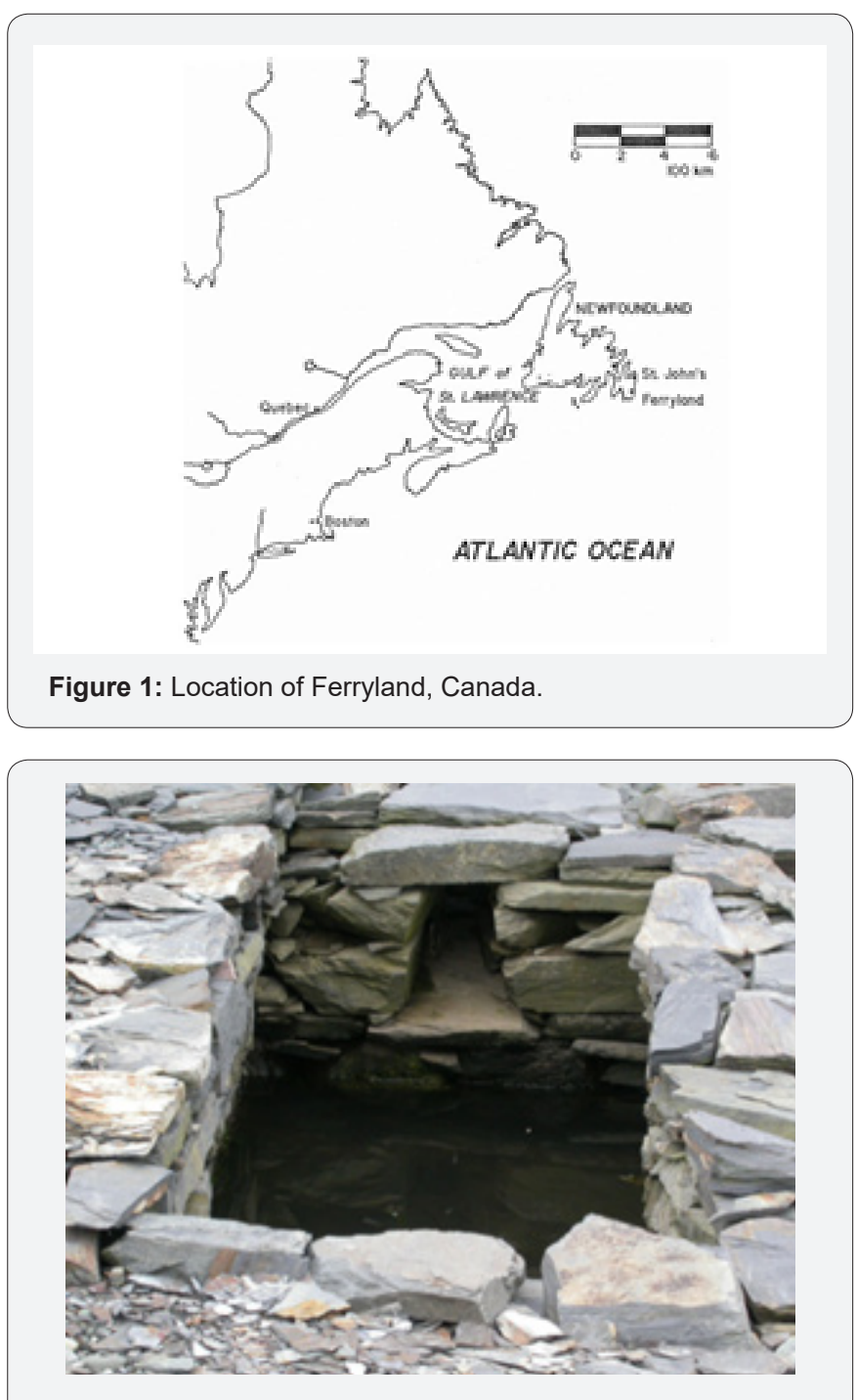

Figure 2: Privy at site in Ferryland; most of the textile remains were uncovered here as clouts or toilet paper. 


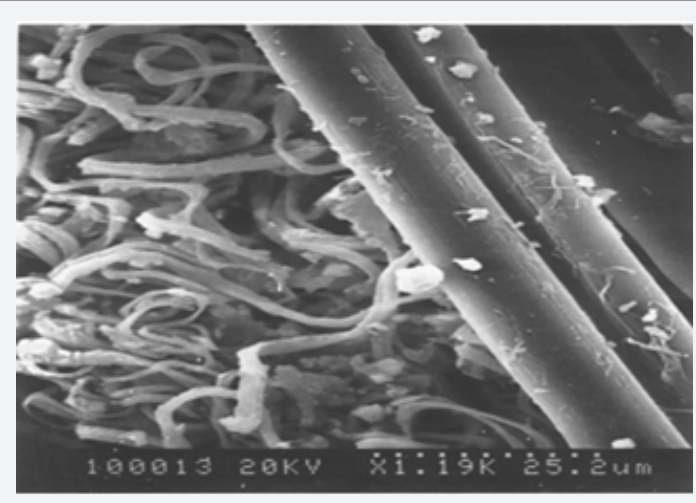

Figure 3: Scanning electron image of silk fibre from privy with nematodes.

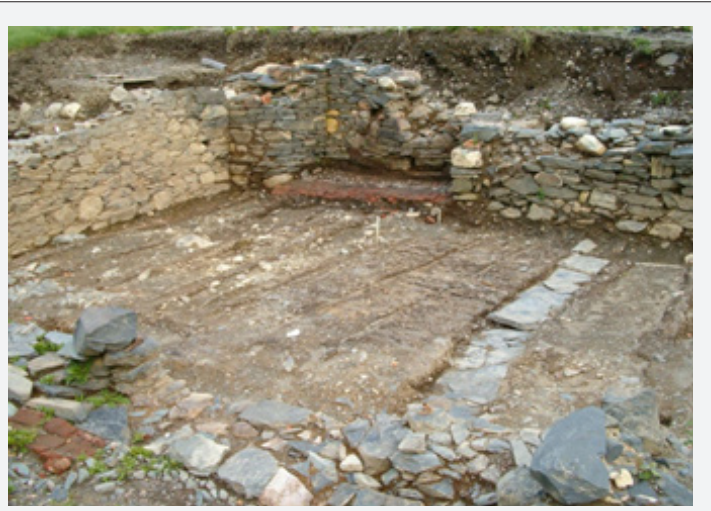

Figure 4: Mansion house at Ferryland; note the remains of plaster on the dry-laid slate stone.

Excavations at Ferryland have yet to locate the colony's cemetery. During the almost 80 years of occupation during the $17^{\text {th }}$ century, people at Ferryland would have died. It is likely that Lady Kirke is buried near the colony at Ferryland [17]. Though the burial environment of the cemetery may not be sympathetic to organic preservation, it is possible that a woman of Lady Kirke's status would be buried in a lead coffin, like those of status found at St. Mary's City buried in lead coffins, which could afford better preservation [18]. Without this additional comparative information our interpretation of the site cannot help but be biased by what has been found to date. One must therefore carefully define the features with which we interpret the costume components of the Ferryland site. The bulk of the textiles are from the waterfront privy. Other related materials come from two middle-status houses, and one gentry house.

\section{Seventeenth Century Textiles}

The following cloth descriptions are based on those used by Kerridge [19]. The cloths are presented in roughly chronological order beginning in the 14 th century and ending in the $17^{\text {th }}$ century. The earlier cloths continued to be used during in the $17^{\text {th }}$ century and therefore are included. These include: says; kersey cloth; Suffolk cloths; worsted says; worsted satins; camlets; russells; silk damasks; jerseys; mixed stuffs; worsted stuffs; baize; flannels; serges; linens and broad silks [20].
Says were tabby-woven while kersey, of a thicker yarn, were twill woven and used for stockings [21]. Serges, produced in Southampton, were also a woven with a thick yarn and fulled to give extra warmth. Serges replaced the kersey wool but were used for more than stockings [22]. Suffolk cloth was dyed blue [23]. Cloth made with longer wool fibres called worsted, such as worsted says or russells, gave a similar shiny appearance to silk but were much cheaper [24]. Russells were therefore used to make gowns, coats and petticoats [25]. Double russells, manufactured in Norwich, were used to make petticoats, spring and summer coats, scholar's gowns, men's vests, waistcoats and women's boot and shoe uppers [26]. Camlets, also produced in Norwich using a highly twisted yarn, were used to make bodices, breeches, drawers, cloaks, gowns, jackets and petticoats. The russells and camlets were a finer cloth [27].

A baize was a mixture of worsted warps and carded weft threads made of shorter hairs than worsted. Baize would have been fulled and was popular to the 1620s. Flannels were similar to the baize with a worsted warp and carded weft. Flannels were used for undervests, underpants, drawers, trousers and shirts [28]. The process of fulling wool cloth required access to water. Exeter, which was beside a large river, had a large fulling mill [29]. Based on descriptions of cloth by Kerridge, it is estimated that most of the 183 tabby-woven wool samples represent russells, camlets, says, serges and flannels. The few samples of $2 / 2$ twill wool could be classified as kersey wools. Many of the kersey wools were used for cloth stockings; when knit stockings became more popular kersey wools fell out of favour [30].

\section{Discussion}

The archaeological record does not preserve all materials left behind by people. It would therefore be unfair to make a judgement on the export English cloth industry of the $17^{\text {th }}$ century based on privy and midden remains from Ferryland. An undisturbed site, such as the Ferryland privy, can provide support for the availability of materials identified in archival documents. The organic components of material culture are generally less well represented in the archaeological record. The most durable of artifacts are those made from inorganic materials. Those artifacts represent house-building materials, such as metal hardware and stone foundations, ceramicwares and glass items related to food preparation and consumption as well as metal tools. Archaeologists use these better-preserved fragments to identify the use of space within structures, types of food preparation, possible foodstuffs consumed, the layout of villages, workspace usage, status and wealth. Textiles rarely survive burial. Sometimes associated costume components will survive, such as bale seals from bolts of cloth, pins, buckles and buttons. This record tends to be less biased by differences in social class than those of the written, print, or image record. For example, when the Ferryland site was attacked by the Dutch in 1673, the resulting destruction and burial of structures and artifacts affected occupants regardless of their social standing. 


\section{Global Journal of Archaeology \& Anthropology}

The destructive nature of the burial environment, however, acts differently for each material type resulting in an incomplete archaeological record.

A thorough examination of costume from the $17^{\text {th }}$ century is fraught with problems, the greatest being the fragile nature of the materials from which clothing items were made. The wools, silks and linens used in the construction of breeches, gowns and shirts rarely survive the test of time. Researchers have examined a variety of North American archaeological sites with textiles remains and have found that, in general, only proteinaceous materials survive, with some instances of cellulosics preserved in the corrosion layers of associated metals [31]. Even when found, not all fibres can be positively identified because morphological characteristic may not be preserved [32]. Associated materials such as metal buttons and buckles also fall victim to the deteriorating affects of the burial and ambient environments.

Desiccating or waterlogged anaerobic environments lead to long-term survival of textile fibres those made of silk and wool [33]. Unfortunately, these burial conditions are rare. The soil conditions of the privy at Ferryland consisted of a wet, thick soil rich in faecal matter which afforded the preservation of both wool and silk. However, even with this wet environment not all components of a textile necessarily survived. Dyestuffs were likely lost to leaching. Historically, natural dyes, generally being fugitive, were used along with a mordant. During the $17^{\text {th }}$ century the common mordants were aluminum, iron, tin or copper. Mordants would complex with the dye and fibre to produce a more permanent dye [34]. Although mordant dyes have a better chance of surviving, they can be masked by staining from the organic matter in the soil [35]. It has also been noted, but not yet published, that weld dyes can act as antioxidants and will help preserve organic textiles [36].

The Ferryland collection contains 237 woven wool samples and approximately 18 cloth fragments made with silk fibres. The textile collection from Ferryland has few silk pieces. If privies were built for use by the gentry who were the most likely to be wearing silk, why then does the Ferryland privy contain so few silk fabrics? Based on the good condition of most of the silk fibres examined, with wear being attributed to use (Figures 1-5), it seems unlikely that the burial environment would preserve some, but not all. This must be a function not of preservation, but rather use, preference for wool by gentry, or availability. This may also be related to differences in climate between Newfoundland and Europe. The cooler temperatures of Newfoundland may have led to many wearing warmer woollen clothes, rather than silk or linen. One possible explanation may be that the Ferryland gentry did not use this privy exclusively or to any great degree. Perhaps the co-operative nature of proprietorship, under Calvert, dictated that anyone was welcome to use the privy. Though the people at Ferryland could have added to the cesspit during its last years of operation, there is a consistently low concentration of silk in these strata. Supply and access to markets also might have something to do with the scarcity of silk. Wool manufactured in England would have been more readily available [37].

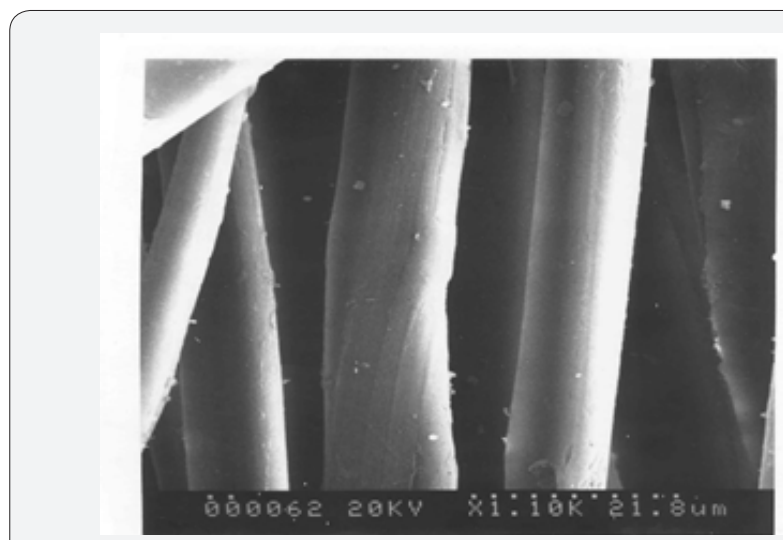

Figure 5: SEM image of CgAf-2:133115 (1100 X).

Fibre condition can tell us something about the use-wear of the privy fragments. For example, about $40 \%$ of the silk fibres examined exhibited cracks perpendicular to the length of the fibre. This type of deterioration is indicative of a fibre that was extensively bent during use indicating that it was worn a great deal [38]. This may indicate that the other $60 \%$ of the collection was not used extensively before being made into clouts. Some of these samples include silk trim which was not likely used for hygiene purposes, but nevertheless suffered little damage during use. Some of the people of $17^{\text {th }}$-century Ferryland, with money, did not appear to put much wear into their silk clothing prior to discarding. Given that shipping to Ferryland was frequent, the movement of goods such as individual costume orders was possible and likely.

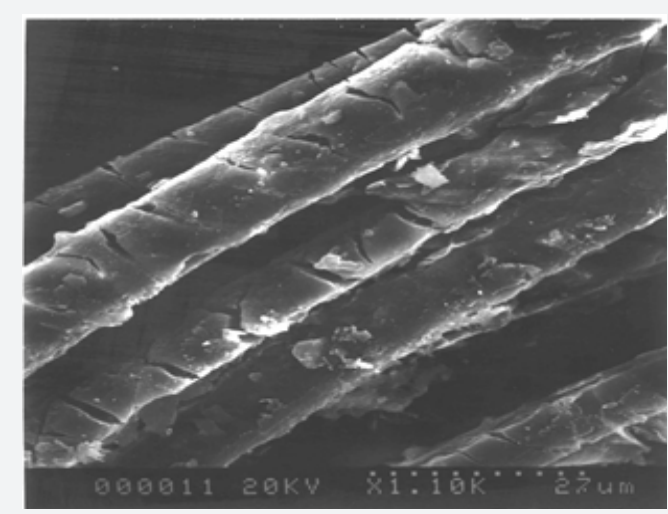

Figure 6: SEM image of CgAf-2:78192 (1,100 X).

Other physical damage, such as microfractures along the shaft of the fibre may be indicative of changes in relative humidity in the burial environment [39]. Figure 6 shows such an example. However, only about $10 \%$ of the assemblage exhibit this type of physical damage. The well-sealed environment of the privy made for a stable environment, based on its excellent state of preservation. 
One other consideration when examining condition is the manufacturing techniques involved in textile production. It appears that the New Draperies in the collection, when examined under magnification, are in better condition than the Old Draperies. This is probably a result of manufacturing techniques. First, most of the New Draperies were dyed. If weld were a popular dye at this time, its antioxidant properties might aid in the preservation of silk and wool. Secondly, they represent finer clothing and may not have been worn as often or for laborious tasks.

The environment of the privy, though stable in terms of relative humidity, resulted in different preservation. Textiles found in the upper layers show evidence of insect attack (Figure 7). Wool found in the lower levels is better preserved and silk found in the upper levels is better preserved. Rootlets were absent throughout the privy. The faecal content of the privy matrix may have inhibited plant growth.

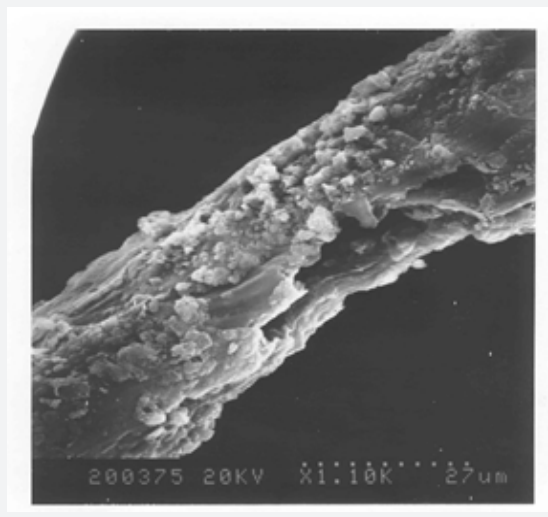

Figure 7: SEM image of CgAf-2:109806 (1,100 X) showing signs of insect attack.

Fungus and bacteria were able to establish colonies once the feature was opened. Both fungus and bacteria can abrade and fracture fibres as they grow within the fibres. Some of this

Table 1: Archaeological Events Associated with the Ferryland Privy.

\begin{tabular}{|c|c|c|c|c|c|c|}
\hline Event Number & $\%$ Textile Finds & $\begin{array}{l}\text { Woven Wools\% } \\
\text { New Draperies }\end{array}$ & $\begin{array}{l}\text { Woven Wools\% } \\
\text { Old Draperies }\end{array}$ & $\begin{array}{l}\text { Woven Silks\% } \\
\text { New Draperies }\end{array}$ & $\begin{array}{l}\text { Woven Silks\% } \\
\text { Old Draperies }\end{array}$ & Date \\
\hline 114 & $0 \%$ & $0 \%$ & $2 \%$ & $11 \%$ & $0 \%$ & $1620 s$ \\
\hline 170 & $7 \%$ & $0 \%$ & $5 \%$ & $11 \%$ & $0 \%$ & $\begin{array}{c}\text { Calvert's occupation and } \\
\text { departure from Ferryland, } \\
1628-1629 .\end{array}$ \\
\hline 116 & $22 \%$ & $9 \%$ & $18 \%$ & $33 \%$ & $0 \%$ & $\begin{array}{l}\text { after } 1629 \text { but before the } \\
\text { Dutch raid of } 1673 ; \text { most } \\
\text { likely } 1630 \text { s }\end{array}$ \\
\hline 111 & $44 \%$ & $14 \%$ & $36 \%$ & $28 \%$ & $6 \%$ & $\begin{array}{l}\text { Later than event } 116 \text { but } \\
\text { before } 1673 \text {, most likely } \\
1640 \mathrm{~s} \text { or } 1650 \mathrm{~s}\end{array}$ \\
\hline 128 & $1 \%$ & $40 \%$ & $20 \%$ & $0 \%$ & $0 \%$ & $1640-1650$ \\
\hline 50 & $12 \%$ & $2 \%$ & $9 \%$ & $11 \%$ & $0 \%$ & Between 1650 and 1673 \\
\hline 49 & $14 \%$ & $1 \%$ & $4 \%$ & $0 \%$ & $0 \%$ & 1673 \\
\hline
\end{tabular}

type of damage can be seen on the fibres, but it is not great. One explanation could be that the backfilling done to over-winter the privy feature after its first year of excavation was successful in creating an anoxic environment, lowering the survival rate of bacteria species [40]. Archaeoentomological analysis of the Ferryland privy indicated a population distribution of beetles as follows: 33\% in Event 116, 30\% in Event 49, 30\% in Event 50, $17 \%$ in Event 170 and $8 \%$ in Event 111 [41]. The percentage differences of entomological remains could be either a factor of population fluctuation, burial environment preservation, or both.

In silk fibres the fibroin decay begins in the amorphous sections. This type of degradation, of crystal structure, results in a loss of orientation making the fibres weak and brittle. Metal thread fragments are often preserved with the core textile, but the substrate textile is missing because of the deteriorating effects of burial. It is therefore difficult to predict to what object the metal threads were attached. It is virtually impossible to distinguish between metal threads used for costume and those used for tapestry as they were produced alike and often in the same shop [42].

Based on the distribution of textiles (Table 1), Event 111 appears to have offered the best environment as $44 \%$ of the collection was found here. This could also indicate a higher rate of consumerism and disposal during this period. Entomological remains were lowest for Event 111 which, if preservation was very good, might be expected to be higher. This may also indicate that consumption was high during this period and that insect population within the colony was low. The highest percentage of silk was found in Event 116, with Event 111 a close second. Entomological remains were highest for Event 116, perhaps indicating that they were consuming silk, with a preference to this keratin over wool. Overall, however, Events 116 and 111 contained the highest quantity of both silk and wool, probably accounted for by environmental preservation but also by the size of the human population, the availability of goods and the ability to purchase. 


\section{Global Journal of Archaeology \& Anthropology}

Table 2: Textiles Found Outside the Ferryland Privy.

\begin{tabular}{|c|c|c|c|c|c|}
\hline Area & $\begin{array}{c}\text { Woven Wool \% New } \\
\text { Draperies }\end{array}$ & $\begin{array}{c}\text { Woven Wool \% Old } \\
\text { Draperies }\end{array}$ & $\begin{array}{c}\text { Woven Silk \% New } \\
\text { Draperies }\end{array}$ & $\begin{array}{c}\text { Woven Silk \% Old } \\
\text { Draperies }\end{array}$ & Date \\
\hline D & $25 \%$ & $25 \%$ & $0 \%$ & $0 \%$ & $1660-1696$ \\
\hline F & $25 \%$ & $12.5 \%$ & $100 \%$ & $0 \%$ & $1625-1696$ \\
\hline G & $0 \%$ & $12.5 \%$ & $0 \%$ & $0 \%$ & $1620-1696$ \\
\hline
\end{tabular}

Table 2 presents the distribution of textiles found outside the privy. Area F contains the only silk remains. This is not likely related to preservation but is more likely a fact that this was the result of the area of a high-status residence where silk would have been affordable and worn. The woven wool New Draperies were evenly distributed between Areas D and F. The Old Draperies were concentrated in Area D which represents a household of middling sorts.

Based on both the information reported by Kerridge, regarding textiles from the 1600s, information garnered from textile researchers abroad and the Ferryland archeological textile collection, it appears that the following cloth came to North America in the $17^{\text {th }}$ century: serge; kersey; resells; camlets; worsted says and satins; flannels; braize; and broad silk.

From the wool textile fragments found in the privy, we know that men could have had clothing constructed from coarselywoven cloth and finely woven twill and tabby cloth. The coarsely woven tabby cloth likely represents a working type of breeches. Breeches waistbands found were of a slightly finer weave, with a 7/9 thread count, and possibly represent a pair of non-fishery working or common breeches. There were doublets with long tabs which were popular in the early $17^{\text {th }}$ century. Fragments which probably represent doublet wings or epaulettes were also present and these match the doublet tabs (in terms of date) that were also present. Fragments CgAf-2:97654a-c and CgAf2:106584 appear to be of a similar twill-woven fabric, possibly from a doublet, and represent the New Draperies. The former fragments are from a late $17^{\text {th }}$ century context from the Area D house, while the latter came from the lower levels of the privy. These samples suggest that one bolt of cloth may have made its way to Ferryland early in the century and was used throughout the century. Or, more likely, this could indicate that similar types of fabric were shipped to Ferryland throughout the century.

The silk lace and silver point, CgAf-2: 90255, are sufficiently short to indicate that it was used for decorative purposes, probably for a doublet [43]. These laces with points remained in use as decoration around the waist of a doublet until about 1630 [44]. There were a few pieces of silk velvet and two fragments of silk damask indicative of high status. Designating fragments as components of male or female costume is difficult as either sex could have worn these fabrics in the $17^{\text {th }}$ century.

Though cellulose-based fibres were not preserved, evidence such as a bale seal, CgAf-2:315014, representing Haarlem's fine linen, indicates that lengths of linen were shipped to Ferryland presumably for the construction of undershirts for both men and women and children. Holland linen, as it was called in England, was widely distributed in the $17^{\text {th }}$ century, based on seals found in London, Northamptonshire, Wiltshire, Edinburgh, France, the Netherlands, Sweden, and the Pentagoet site in Maine [45]. Examples like the British Museum seals have also been found at St. Mary's City dating to the mid-half of the $17^{\text {th }}$ century; these may more closely match the Ferryland seal [46]. Though the Ferryland seal is like the British Museum example, the numbers inscribed on the seals, which represent cloth length, are different.

The silk damask fragments appear to be French since they matched similar samples of damask from France in the Victoria and Albert collection and in the Royal Ontario Museum collection. Most of the wool samples were probably manufactured in England. Silk trim, ribbons and samples of passementerie were possibly manufactured in London by Flemish textile workers [47]. Metal thread production is recorded as having been carried out in Nuremburg from the $14^{\text {th }}$ century [48]. It is likely that there were other, non-recorded, sites of metal thread production.

Was this rapid transfer of fashion to the Colonies a result of goods being imported directly from England or were they shipped between the North American colonies such as Boston? Or was it because print images were imported bringing news of change? Each likely contributed equally, given that the costume remains seem to indicate that a relatively fashionable population resided in $17^{\text {th }}$-century Ferryland.

The likely manufacturing centres used for the textiles represented within the Ferryland collection include England, Germany, France and the Netherlands. The fact that shoe buckles show up at Ferryland within a 1660s context indicates that costume fashion and news of its change was available to at least some of the residents of this colony. We also know from documents that shipments of ready-mades numbering in the thousands were coming to Newfoundland; no doubt some were delivered to Ferryland [49]. The ready-mades were likely intended for the middling sorts or their servants. The silk damask and the fancy snuff box may have been produced in Lyons, France. The silk ribbons were likely produced in Germany or the Netherlands. Some of the porcelain came from the Netherlands, while most of the stoneware mugs, jugs and bottles came from Germany [50]. We know from bale seal evidence that fabric came to Ferryland from Exeter and London. The silk damask samples found in the top layers of the privy, which represent the last phase of its use in the 1670s, seem to best match a French provenance. The tulip and leaf pattern are very similar to those fragments of silk fabric with a French origin in the collections of both the Victoria and Albert Museum and the Royal Ontario Museum. That such rich silks were disposed of in the privy 


\section{Global Journal of Archaeology \& Anthropology}

and not reused indicates a certain amount of wealth within the colony, at least by those living near the privy (perhaps by those of the Kirke household). We see evidence for the purposeful reuse of textiles in the middling household of Area D. The elaborate designs used in textiles and on other material culture in the $17^{\text {th }}$ century, provide evidence for the movement of consumables and people beginning in Medieval Europe and through the early modern period. Both periods are often viewed by the current culture as unsophisticated, uninspired, dark and without human comforts [51].

The material culture, however, provides evidence to refute this notion, as illustrated by the artifacts described here. The remnants of early works of art, revealed through conservation provide further support [52]. Seventeenth-century Europe underwent a great period of discovery, expansion, and movement in terms of trade. The discovery of the Americas and passage to the East Indies via the Cape of Good Hope changed the movement of goods and world trade forever. A routine exchange of commodities developed in which the Newfoundland fishery was a significant component [53]. Contact between Europe, America and Asia through commerce exposed Europeans to foreign cultures through their goods (motifs were exchanged along with raw materials) and reshaped Europe's perception of itself and its place in the world [54].

Dyestuffs can also tell us something about trade at this time because they were a valuable commodity and were documented by their place of manufacture [55]. Known dyes were identified on 24 of the 59-fibre sample. In 15 samples compounds indicative of red dyes (carminic acid, alizarin and purpurin) were identified. Carminic acid was identified in four burgundy silk samples. It was the only dye detected in two of the silk samples (CgAf-2:127294 which was a burgundy brown silk brocade and CgAf-2:124936 which was a burgundy silk). Two other silk samples contained alizarin and purpurin, as well carminic acid (CgAf-2:101147 which was a burgundy silk thread trim and CgAf-2:124974 - burgundy brown silk brocade).

Nine wool samples and one silk sample contained alizarin and purpurin or just one of the two dyes but no other dyes. Both components were detected in seven samples, a brown silk satin (CgAf-2:126469), three brown wool twills (CgAf-2:101991, 112648, 124990), a brown wool tabby (CgAf-2:101202), and two green brown wool twills (CgAf-2:124957 and 124995). Purpurin, but not alizarin, was detected in a green wool (CgAf2:109810) and a dark red brown wool (CgAf-2:127320) that also contained gallic acid. Alizarin was detected in 109020, a brown wool twill that contained some red fibres.

The hydroxyl flavoneluteolin was identified in seven fibre samples: three green silks (CgAf-2:78130, 87101 and 124904); three brown wool twills (CgAf-2:67517, 78130 and 148115); and one yellow wool twill (CgAf-2:124994). Luteolin was detected in two samples from artifact CgAf-2:78130, one brown wool fragment from a jacket, and the other green silk from a button hole.
Logwood was present in two black wool samples with a twill weave (CgAf-2:97640 and 230445). Chromium was detected by $\mathrm{x}$-ray microanalysis in the same samples and alizarin was also detected in CgAf-2:97640. Logwood was used as a substitute for woad, and though fugitive, produced a purplish blue [56]. Because of its fugitive nature, this dye was banned in England until a method for making it fast was introduced in 1605 [57]. This dye could therefore have been used to produce a black or blue cloth [58].

The dyes identified include those common to the period. Madder was the most common dye after woad in the $17^{\text {th }}$ century [59]. Not surprisingly therefore, madder was identified on more samples within the Ferryland collection than any other dye compound. Cochineal, an expensive dye, was identified only on the silk fragments. Madder and weld were identified on both wool and silk. Weld, or dyer's weed, was one of the major sources of yellow [60]. Logwood dye was identified on wool. Samples which tested positive for tannin included 15 wool and 11 silk fragments. Samples which tested negative for dyestuffs included nine wool samples. Un-dyed wool was not uncommon at this time and it is therefore unsurprising to find some wool samples without dyestuffs, although this may represent leaching by the soil matrix. Though tests for blue dyes were performed none were found, apart from the 18th century Prussian blue.

An overall view of the textiles based on the results of dye analysis indicates that textiles were coloured either red or yellow. It is difficult to speculate as to why there was a preference for red and yellow at Ferryland. Cunnington cites a reference to the wearing of blue at this time, to be used for the dress of apprentices and servants [61]. If this is in fact true, it might suggest that the Ferryland privy was used only by gentry. Or it could simply be that supply ships did not go to areas where bluedyed textiles were manufactured. Kerridge notes that Suffolk cloths were a true blue in the wool. Here woad and indigo dyes were used to create a range of shades [62]. Neither cloth bale seals nor other material culture excavated at Ferryland, to date, indicate a trade link with Suffolk. Woad was not grown in large quantities in England until the 1560s [63]. Though both madder and weld were grown domestically, most of the madder was imported from Flanders and Zealand [64]. Other dyestuffs were imported, gall-nuts (used to fix logwood) from Venice, cochineal from Central and South America, and logwood from the West and East Indies, Central and South America and Virginia [65].

The high percentage of tannin identified along with the two logwood dyes might allow one to speculate that these represent a black or blue dye. Aluminium and iron elements identified could represent mordants used to make the dye fast [66]. The absence of woad or indigo, within the collection may be explained by the fact that logwood was used to produce blue.

Extant costume provides further evidence of what was available for English consumers in the 1600s. Based on this evidence, and the fragments found at Ferryland, one may think that costume was used as an identifier of status in North 
America to the same extent as it was in England. The question as to whether or not costume was used as an identifier of social change in the colonies is much more difficult to address because of limited accounts of society there. Excavations at sites comparable to Ferryland, such as Jamestown and St. Mary's City, are not yet complete; archaeologists and anthropologists continue to investigate and interpret social changes through the analysis of artifactual and structural remains. The changes that occurred at Ferryland are as follows: documentary records indicate that Sir George Calvert initially ran the early colony as a co-operative venture from 1621 to 1634; but when Sir David Kirke and his family arrived in the late 1630s, the colony's cooperative nature changed to an entrepreneurial one where taxes were levied.

The price of cod and its abundance fluctuated throughout the 1600s and the colony was attacked by the Dutch in 1673 but continued until the French attack of 1696 [67]. It seems that from about 1640 to 1670 , the colony at Ferryland, under a capitalist vision, experienced a significant gain in wealth [68]. Potentially, the colonists had greater buying power during this time. Boats were coming and going more frequently which made it possible for costume-related items to be readily available at Ferryland. Based on links between Newfoundland and English ports, drawn by Pope, an estimated 86 boat crews from Jersey, London, Southampton, Torbay, Dartmouth and Plymouth may have brought goods to Ferryland in 1675 [69]. Therefore, the same social changes that came with the Reformation in England, and the associated changes in costume such as rich textiles, ribbons, expensive dyestuffs, could have been seen at Ferryland. Textile remains support this interpretation.

From inventories and cargo manifests, one sees that there was a consistently high demand for alcohol and tobacco among the colonists at Ferryland; likewise, there was demand for bolts of woollen cloth [70]. What did the consumption of luxuries such as wine and tobacco say about the men and women who lived and worked in $17^{\text {th }}$-century Ferryland? It could mean that if they could afford luxury grocery items to be consumed in Ferryland, then they likely had and consumed luxury costume and household goods as well.

Weatherill argues that the material culture associated with domestic life was closely linked to the practical everyday lives of the household and it is within this everyday existence that one will find the meaning of consumption [71]. Most archaeologists would agree that the objects recovered from a house structure reflect the main activities of that household. Therefore, an understanding of consumption patterns could be gained through the examination of excavated objects. One could assume that costume and household textiles would offer similar insights. In considering patterns of consumption for Ferryland in the $17^{\text {th }}$ century, one must be cautious however, because the fragments analysed in this dissertation are discarded materials. The time lapse between use and discard particularly for the specimens from the privy could change the interpretation of past consumption patterns.

There would have been goods consumed that did not wear-out and were therefore not disposed of. Both the privy contents and those from middens do provide us with hints of the goods that came to Ferryland, either with the colonists themselves or on ships as trade goods. Costume can be viewed as an object of necessity in that it serves to protect the body from its surrounding environment. Unlike a bowl for consuming food which may or may not be absolutely necessary, clothing became not only a consumable with practical meaning, but also one which could be used to identify an individual. Textiles as a commodity are personal products. For centuries, they have been used to drape the body, wrap the wearer, seductively or modestly, for public viewing; textiles likewise can be used as swaddling clothes at birth and a shroud at death [72]. Because fabrics are woven, flat and generally absorbent, they have also served as a substrate for applying decoration via embroidery and colour via dye compounds. In this way, an applied decoration or colour could become a cultural signifier or emblem of status. One must, however, first determine whose culture is being interpreted. For example, the motifs on $1^{6 \text { th }}$-century Spanish silks, which were a blend of Chinese and Islamic symbols, influenced silk production in $17^{\text {th }}$-century Europe and England [73]. During the $17^{\text {th }}$ century, the French, dominated the silk industry, but the English silks became popular at the end of the century. Examination of extant textile reveals the incorporation of foreign motifs and designs into European culture [74]. Manufacturers, wanting to please their clients, also blended traditional textile designs and motifs to suit the tastes of European customers [75].

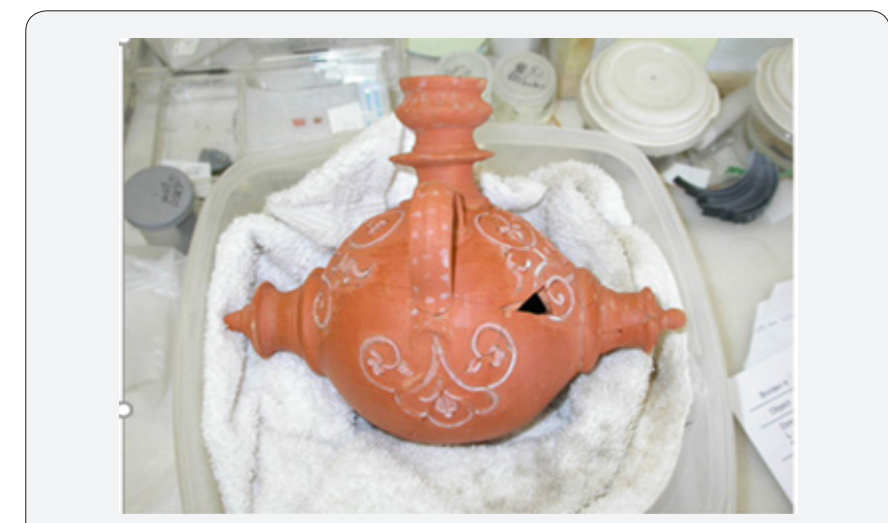

Figure 8: A Portuguese ceramic vessel with Islamic-inspired design, CgAf-2:478369.

By the end of the $17^{\text {th }}$ century, because of demand, much of Asia's goods for export were mass-produced; a similar trend occurred in Europe. This included pottery, fabric and gowns. Thus, because of the desire to mass-produce goods, the motifs on silks became blended and adapted to fit with this need and ideology of rapid manufacture. Elements which might have been distinct to the Tang dynasty or of Islamic origin were stylized and attributed to the French or Spanish cultures. For 


\section{Global Journal of Archaeology \& Anthropology}

example, within the ceramic remains at Ferryland, we see the incorporation of Islamic design on Portuguese ceramics (Figure 8). Other imported goods, such as Chinese porcelain, are also visible evidence of different cultures. Porcelain represented the high status of the owner of such items. One piece of high-quality porcelain, CgAf-2:377874, probably a tea bowl with base and rim section, was excavated from an early $17^{\text {th }}$-century context in the Kirke house.

By the late $17^{\text {th }}$ century, England's economy had changed yet again with the wealth of the country being shared among those of the middling sort. This ultimately meant that luxury goods found a wider consumer group still further down the social ladder [76].

For example, a hair comb, CgAf-2:508922, found in the area of the Kirke house could have been owned by one of the lower sort working or doing business for the Kirke's (Figure 9). By the 1600 s goods from different parts of the globe were being traded within Western Europe. This practise became fairly standard by the end of the century. At this time, the less expensive exotic goods were available to the general population.

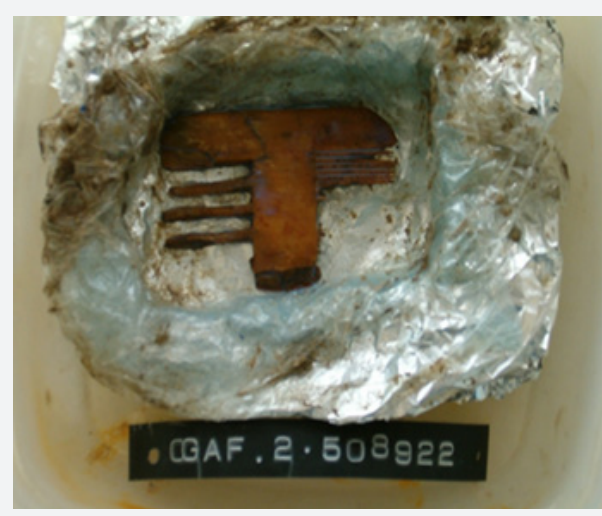

Figure 9: Tortoiseshell comb, CgAf-2:508922.

Exotic goods such as tobacco, tea, chocolate and coffee also were consumed by everyone. These commodities, however, were consumables, though for some, additional props would be added to the ritual of consumption, for example tea drinking rituals complete with table settings or the tobacco pipe for smoking. Therefore, consumable commodities generally did not have a lasting life. They were visible in the course of their consumption but then they were gone. For the consumption of tobacco, coffee and tea, an addiction could develop, and a routine of consumption created. In this example the consumption of the commodity would be visible but not always constant [77]. The large number of tobacco pipe fragments, excavated at Ferryland (Table 3) provides evidence of extensive consumption of tobacco, a luxury grocery at Ferryland. Textiles by contrast, would be a more visible commodity either worn on the body or as part of the domestic space as curtains, bedding and pillows where decoration and colour potentially would have a greater meaning.
Table 3: Frequency of Pipe Fragments by Area of Excavation.

\begin{tabular}{|c|c|c|c|c|c|}
\hline Area B & Area C & Area D & Area E & Area F & Area G \\
\hline 683 & 3,456 & 1,149 & 233 & $22,754^{*}$ & 2,669 \\
\hline
\end{tabular}

* 16,000 fragments were recovered from the "Kirke House".

The $17^{\text {th }}$ century was a period of increased consumption of commodities by the middling sorts and to a lesser degree by labourers. As noted by Wetherill, in her study of window curtains from 1675-1725, consumption patterns are not predictable because factors, such as availability and differences in sensibilities, are difficult to determine. In the case of window curtains, a luxury good, the highest percentage of curtains were found among the middling sort followed by the gentry [78] The material culture, excavated from the middling domestic structures, such as Areas B and D, support this observation made on the basis of probate documents [79]. Documentary evidence shows that the population at large was aware of the link between providing evidence for ones social life through consumer goods [80].

In $17^{\text {th }}$-century England, the household was still, in most cases, the site of both production and consumption [81]. Changes in demand within the textile industry resulted in changes in production. The increased popularity of the New Draperies which required finer worsted wools, dyes and broader looms took the industry out of the home and into a central, often urban, area [82]. This change has afforded better records for researchers to examine. Therefore, a better understanding of what was available to purchase at this time was garnered through the factory records. Understanding what was available to those in North America is much more complicated. Firstly, records specific to consumption of goods in North America seem limited. Probate inventories did not always survive as they were initially sent back to London for storage. For most of the 1600 s consumerism in North America was dependant on the rate of trade between the America's eastern seaboard and Europe. References to clothing were not always recorded [83].

We may not know exactly what the nature of textile consumption was for Ferryland, because of the lack of preservation of textile remains and a paucity of historic documents, but because it is clear that textiles were not produced in Ferryland and therefore had to arrive by boat, we can look for other evidence of foreign textile consumables. These foreign consumables were shipped on vessels which most likely held bolts of cloth and ready-made goods as well. For our purposes the presence of the New Groceries, tobacco, sugar and caffeine drinks, can be used to indicate the availability of consumables at Ferryland and wealth of the colony.

Within the archaeological record, the tobacco clay pipe is the most ubiquitous of all items used to consume the New Groceries. Tea bowls or mugs can be used to indicate the presence of tea or coffee, but these could be used for other fluids at times when the intended drink was unavailable. We know from both 
documentary evidence and archaeological examination that neither tobacco, sugar cane nor cocoa beans were grown in Ferryland; these plants simply could not grow in Newfoundland's sub-artic climate [84]. Because of this, the presence of tobacco pipe fragments is directly related to the importation of tobacco to the colony. Therefore, an examination of clay pipe fragments from the Ferryland site, used as an indicator of the availability of tobacco, can likewise also demonstrate that ships coming to the colony brought goods for trade and not just to pick up dried cod to return to European ports for sale. An examination of clay pipe bowls is therefore used here to give an overall idea of the extent to which the relatively new habit of tobacco smoking was adopted by the people of Ferryland. The clay pipe was in use from the early 1600 s to the 20th century. As a dating tool, however, clay pipes changed stylistically and often had a datable maker's mark applied, which allows it to be used to date strata in the archaeological record [85]. It is not within the scope of this thesis to examine all pipe bowls to separate early ones from later ones. As shown in Table 3 this would require a significant amount of work, some of which has been done by past MA students at Memorial University [86]. For this research, the presence of the early pipe bowls at Ferryland is evidence of ships bringing tobacco and, potentially, other goods such as textiles.

All of the material remains found at Ferryland were manufactured off the Island. The artifactual remains, approximately 1.5 million to date, are too numerous and varied to represent objects merely brought to Ferryland by the colonists. Though some of the material found was no doubt brought by families, most represent objects of trade. There were three means by which trade goods reached Ferryland, the sack ships (20-80ton vessels), the fishing ships (50-130ton vessels), or by the practice of portage [87]. The sack ships which sailed to Newfoundland in the summer to buy fish from planters or buy-boat fishermen (inshore fishermen) were likely the source of most foreign goods [88]. Portage was the right of a sailor to carry goods to a particular location for the purpose of re-sale. This was allowed in lieu of wages [89]. Smaller items such as textiles and costume-related material were likely transported to Ferryland by this practice.

While viewing textiles at the Victoria and Albert museum, a selection of wool textile fragments from the Museum of London were examined. These textiles, representing fabric fragments discarded in the Thames, were similar in weave to some from Ferryland. These fragments from the Thames were broadly dated to the 16 th and $17^{\text {th }}$ century and $70 \%$ of them were New Draperies. This confirms that New Draperies were readily available in London currently.

The madder identified in the Ferryland samples also tested positive for alizarin [90]. This is considered typical for wild madder Rubia Peregrina which contains 11\% alizarin. Another discovery in the Ferryland collection, is that madder and cochineal were mixed to form the colour in many of the silks
[91]. Samples which tested positive for tannin included 15 wool and 11 silk fragments. Samples which tested negative for dyestuffs included nine wool samples.

What do the small finds tell us about life in Ferryland? Researchers believe that shoe buckles began to be used during the last quarter of the $17^{\text {th }}$ century [92]. Within the Ferryland collection shoe buckles are present at about the same time. Approximately 30 two-piece buckles, no two alike, which may have served as shoe buckles, were found at Ferryland contexts from the second half of the $17^{\text {th }}$ century. Three of these were made of silver, the others of a copper alloy. For a colony with a population of some 150 people, this could mean that $20 \%$ of the population was wearing buckled shoes by the second half of the century [93]. Only three two-piece buckles were found at St. Mary's City and no buckles of this type were found at Cupids. This suggests that shoe buckles were more available to Ferryland and that colonists had sufficient money to buy them.

Coins likewise contain information about costume [94]. One Ferryland coin depicts a falling linen collar. This coin, CgAf2:298218, is identified as French and dates to the 1630s [95]. Where exact dates are lacking, items of material culture which incorporate costume from extant or archaeological examples can be used to confirm dates. For example, a similar collar at the Gallery of English Costume, Manchester, M7755, has been dated to the $1620 \mathrm{~s}-1630 \mathrm{~s}$ which coincides with the date assigned to the coin. Likewise, tin-glazed ceramics of the $17^{\text {th }}$ century also incorporate figures dressed in costume of the period. Where archaeological samples may lack an exact date, the costume depicted can be used to provide an estimated date. Like printed images, however, one must assume that the costume depicted is contemporaneous with the object's date of manufacture.

Self-importance based on the public image one created was significant during the $17^{\text {th }}$ century. The nobility, gentry and middling sorts strove to be up-to-date with the latest fashions as observed in documentary evidence, paintings, prints and extant costume. The archaeological remains, which usually provide an accurate reference for dating, also support this observation.

The growth of venues for public gatherings such as the coffee houses and taverns also contributed to the growth of this display culture. People were out in public and wanted to be seen at their best. No longer was the home the only showcase. While in public view one's attire would provide a visual image of their place in society. The growth of print culture also drew people into public venues. The number of pamphlets produced in England grew from 22 in 1640 to 1,966 in 1642 [96]. Coffee houses were popular and available to all. Here broadsheets could be read and, in some cases, read to an audience. Here was a place to acquire knowledge of the current events.

Some of the questions answered here touch on the traditional themes of historical costume studies: the textiles' poor preservation; incomplete archival records, such as the 
undocumented exchange of costume goods; and an incomplete depiction of life in the contemporaneous visual record. Extant documentary records from the $17^{\text {th }}$ century should be further explored to reveal additional information regarding costume. Further aspects of the adaptation of costume should also be examined. More work could be conducted to identify evidence of dye plants being grown in $17^{\text {th }}$ century Ferryland. In addition, evidence for sheep herding and weaving could be examined. On-site excavations at Ferryland and continued analysis may uncover some of this information. For example, does the quality of textile remains increase when the Mansion house is found? If the cemetery associated with the site is uncovered, and if its contents are well preserved, one might gain information regarding the quality of complete costumes. With further excavation, the distribution of people in their living quarters may be revealed. Did the colony always have a resident tailor? Was there more than one at any time during the 1600s? Further excavation could reveal a storehouse of cloth and other supplies used by a tailor. All of these questions could lead to a greater understanding of the independence and co-dependence of Ferryland's $17^{\text {th }}$-century population in relation to England and Europe in reference to costume.

Seventeenth-century England could be characterized as being a time of internal turmoil [97]. It was also a period of colonization of foreign lands and an increase in technological advancements. For example, the facets cut on a crystal drop, (Figure 10) CgAf-2:402107, would not have been possible in the previous century. Perhaps both the conflict within England and a desire by the nobles and gentry sorts to explore outside of England lead this nation to succeed in the transplanting of people to places such as Ferryland, Newfoundland. The Calverts and Kirkes left England for a more peaceful existence in Ferryland. Outside of the reaches of parliament and the monarch, this colony flourished, possibly because it was less affected by the politics of the time.

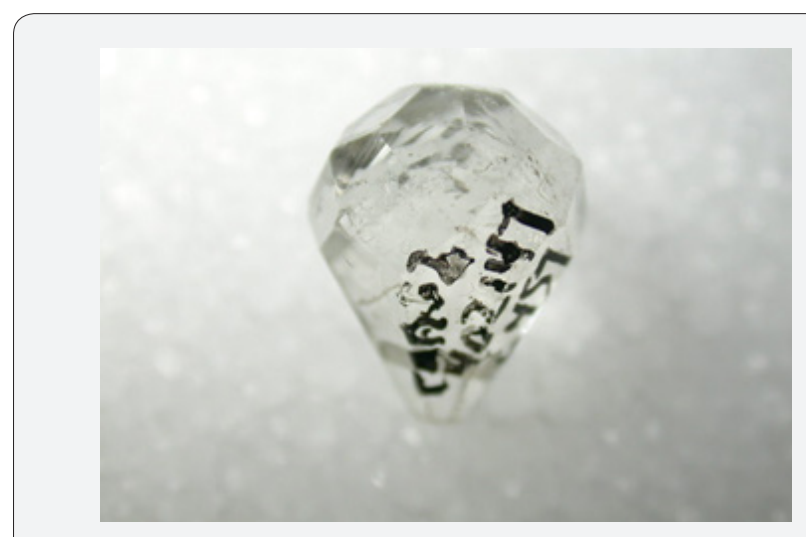

Figure 10: Facetted crystal drop, CgAf-2:402147.

In terms of costume for the Ferryland site, we are questioning whether the growth in fashion in post-Medieval European populations was carried over to those colonizing North America.
Could regional differences be identified, in this case, between England and the Colony of Avalon? Did changes in fashion and culture in England also occur in Ferryland? If so, was this at the same rate or was there a time lag because of distance form the cultural hub of London? Do we see signs of adaptation in terms of costume this early in the historic record?

The small finds, which constitute the associated costume components and the fragile organic textiles often don't survive because of the aggressive nature of the burial environment; hence the cold, moist environment of Eastern Canada aid in the preservation of some significant textile finds.

The degree of artifact preservation does make predictions of culture difficult. The non-ferrous metals used to produce the buttons, buckles and other costume components are well preserved at Ferryland. One can therefore draw some conclusions about the status and general standard of living based on what has been preserved. One must, however, be cautious and mindful that the colonists relied on what they brought with them and what was available on the sack ships and fishing ships that visited Ferryland's harbour. To date, the bulk of the textiles, have come from a privy feature which provided an almost anaerobic moist environment sympathetic to their preservation. These fragments, however, represent re-use; although this serves as evidence of the types of fabrics used at Ferryland, their dates are poorly defined. We know that the privy was in use from the 1620 s to the 1670 s and that it contained a high proportion of the New Draperies. During the $17^{\text {th }}$ century privies were usually used only by the gentry sorts. The group of textiles found in the Ferryland privy generally support this. The Nanny privy in Boston also contained fragments of luxury textiles; this privy was associated with a high-status household of the late $17^{\text {th }}$ century. Though the dates of each privy do not correspond, for comparative purposes textile and costume pieces made their way to North America throughout the $17^{\text {th }}$ century. It appears that this is the case for English settlements early in the century.

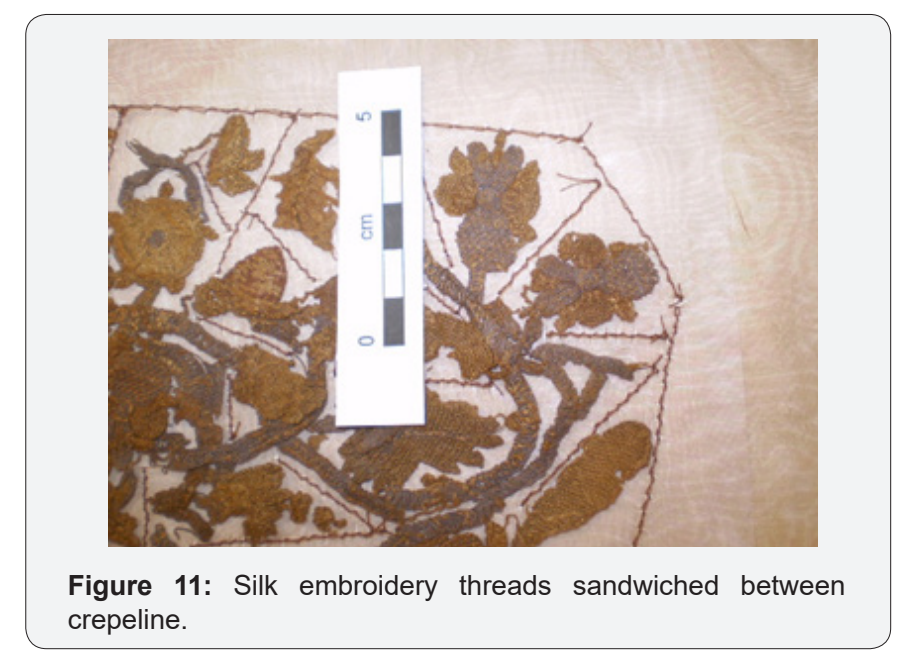

The contents of the privy are the most significant repository for textiles. The textiles are divided between tailor's scraps 
made mostly of silk and square fragments of wool used for hygiene purposes. The former represents the gentry and the contemporaneous creations of a tailor. The latter represents reuse of worn or out-of-fashion clothing items. One might also divide the contents by their quality and cost with silks representing greater luxury than the wool. Overall, however, given the large quantity of the New Draperies, the dyestuffs used, and weave structures, it appears that the colony was not poor, but instead offered a high standard of living for all. Another collection of textile fragments was a lump of embroidered threads on a silk substrate. When unfolded, cleaned with water and freeze dried this lump seems to resemble a women's embroidered jacket dating to 1620 on exhibit at the Museum of Costume in Bath, England. Figures 11-14 show some of these embroidered threads.

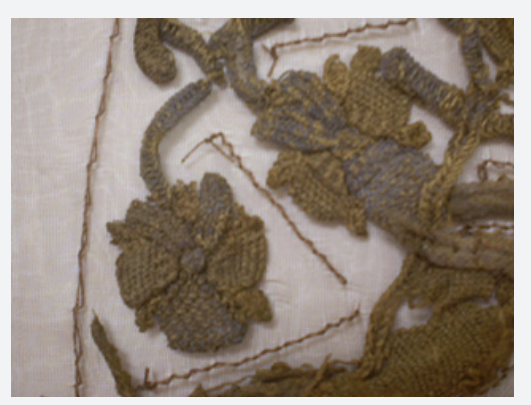

Figure 12: Embroidery threads; note the Tudor rose motif.

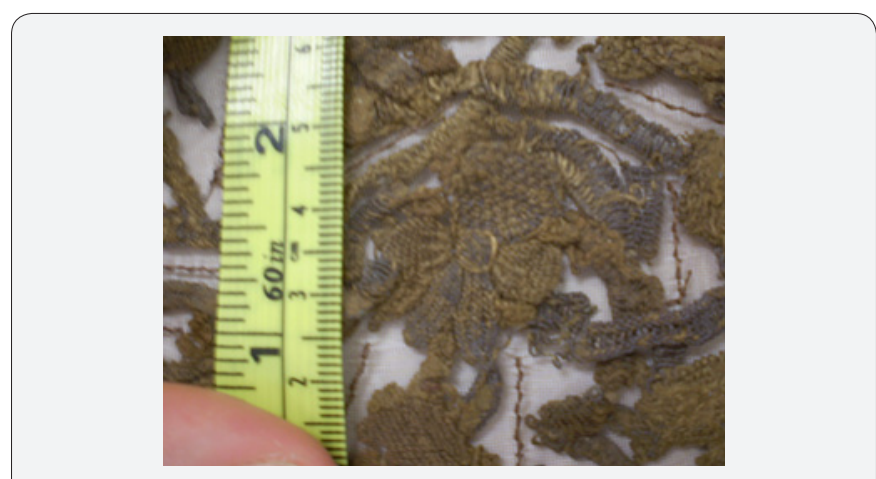

Figure 13: Detail of silk embroidery threads.



Figure 14: Embroidery threads.
In a broad sense, historians and archaeologists have examined the colonisation of the New World in the early modern period to document adaptations to a new environment, the transfer of Old World ideas and technology and the invention of new solutions. This thesis further contributes to this research. Differences in the Ferryland privy with its high wool content and the Boston privy where silk was dominant may provide evidence of adaptation by gentry to the cooler climate of Ferryland. The material culture found at Ferryland, in terms of both costume and non-costume related goods, indicates that there was a rapid transfer of commodities from Europe. This is not surprising given the volume of shipping essential to the region's cod fishery. The fact that boats came to Ferryland did not necessarily mean they would bring commodities for consumption. This would have occurred only if there was sufficient wealth to pay for such goods. The overall quality of material culture found at Ferryland supports the notion that there was indeed essential wealth to bring in such goods. Did those living in $17^{\text {th }}$ century Ferryland attempt to emulate their English domestic environment? Overall building construction, though not as grand as that found in England, appears to be based on English styles [98]. The rise of the middling sort is of importance here as the archaeological evidence at Ferryland clearly indicates the presence of middling and gentle folk. The middling sort comprised a newly-defined social group in the late-seventeenth century [99].

Though the items of jewellery found at Ferryland are relatively few, the range in quality and value from middling to gentry, which fits nicely with the range in status of those at the colony. Moreover, most of the items of jewellery available in the $17^{\text {th }}$ century is represented at Ferryland.

\section{Conclusion}

An examination of textile, jewellery, buttons and buckles along with the ceramic assemblage from Ferryland clearly indicates that many colonists had wealth and brought some fancy items with them. This contrasts with the colony's gentry buildings which were in general smaller and less extravagant than homes of the gentry in England [100-136]. At a time where visual presentation was important, this is one aspect of the Ferryland colony that fits poorly with activities back in England. Captain Wynne and other colony managers had a vast quantity of building materials available to them in the surrounding area. Perhaps a knowledge of piracy in the area influenced the building style to such a degree that the colony was purposely built as a middling settlement and therefore not worth the effort of attack. Costume could be displayed or hidden on demand. It appears that the people of $17^{\text {th }}$-century Ferryland used personal belongings and costume to identify their status [137-180].

What is certain at this point is that William Sharpus, a tailor, arrived in Ferryland in 1622 to practice his trade. From excavated bale seals, we know that cloth was sent to and unloaded at Ferryland. Given the presence of a tailor, one would expect to find some archaeological remains to support this occupation 
[181-210]. Numerous thimbles, pins, scissors and scraps of cloth have been found, all of which support the presence of this activity. This may be one indication of self reliance on the part of this community of some one hundred and fifty souls.

The print culture studied here provides further evidence and support for the material culture found at Ferryland being from the $17^{\text {th }}$ century. Each dated print contains a fragment of costume detail from the past, such as buttons, hats or shoes, which have been found in the $17^{\text {th }}$ century context at Ferryland [211-238]. Though there is little more that can be said here, from an archaeological point of view this conclusion is significant. Because the burial environment is not a complete picture of the past, many mis-interpretations can be made. The $17^{\text {th }}$ century print culture represents a resource yet to be utilized by archaeologists.
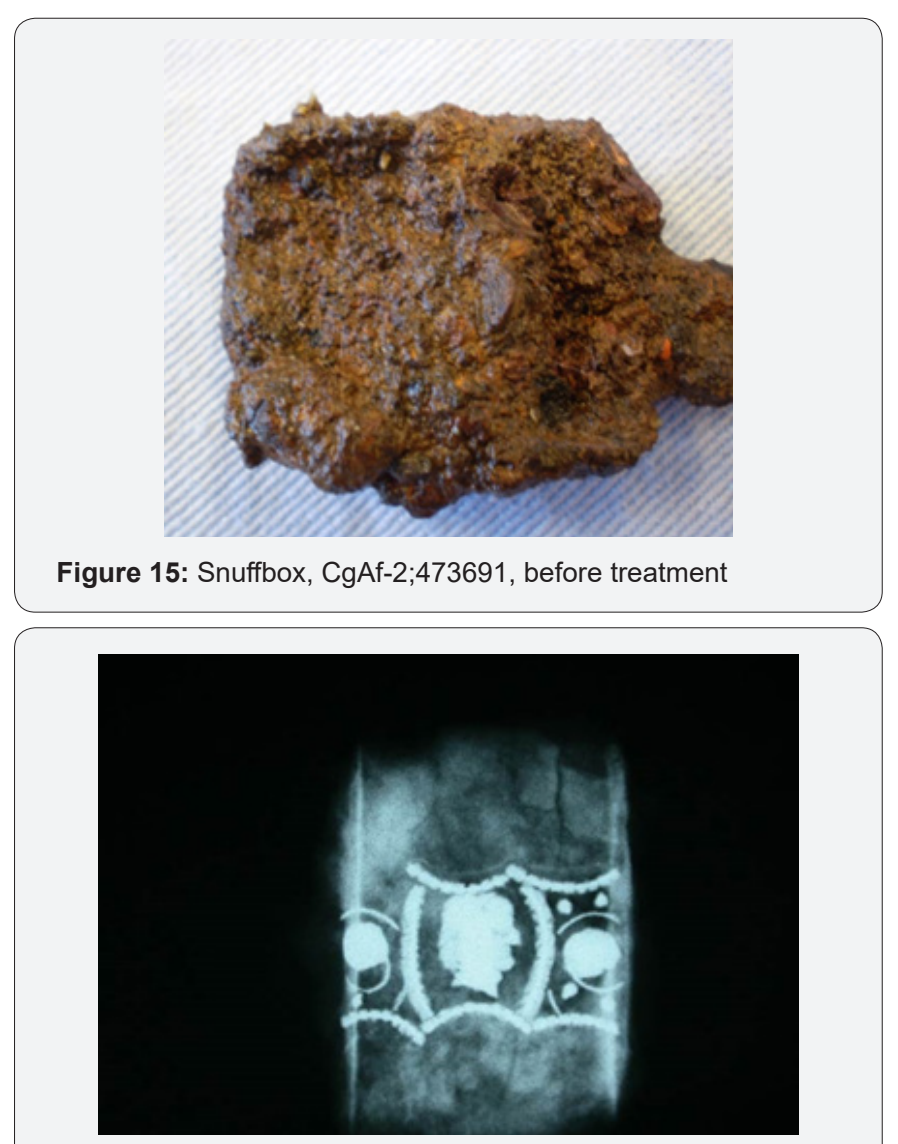

Figure 16: LX-radiography of snuffbox CgAf-2:473691.

Through the one hundred years of textile finds from Ferryland, Newfoundland, there were many changes in the textiles and related artifacts from the course Old Draperies to the finer and softer New Draperies and from ties to covered wooden buttons to cast metal buttons. The footwear gained height with heels, shape and colour with dyes. The hats went through many stylistic changes, but also material ones from knitted woollen caps to tall shaped beaver hats. A man's costume developed into one which included breeches, vest and coat - the suit which is still worn today, though appearing somewhat differently in style.
The $17^{\text {th }}$ century was a time of many political, environmental and economic changes. The English colonized new lands and continued to grow as a world empire. How people perceived themselves and how they dressed themselves to be perceived by others could not help but change in such a climate. The century to follow would bring even more elaborate costume as the country continued to grow. It was, however, the great expansion of Europe through colonization, (Figure 15-17) in the $17^{\text {th }}$ century, of which Ferryland, Newfoundland was an important part, that set the path for the $18^{\text {th }}$ century.

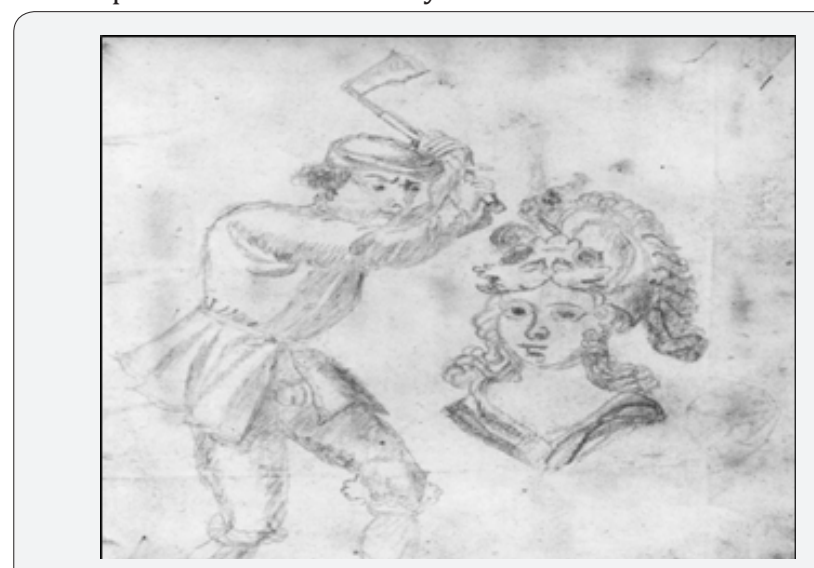

Figure 17: A sketch found in Captain Wynne's journal titled "The British India or A Compendious Discourse Tending to Advancement", undated, graphite on paper, British Library Collection 17.a. Lviip.262.

\section{References}

1. Caesar Papers, Treasury and Privy Council, Lands downe MS.152.

2. Colonial Papers (1662) Provincial Archive of Newfoundland and Labrador, photocopies of microfilms of original documents in the British Archives.

3. The History of Common Practises in Dying (1662) In Sprat's History of the Royal Society. British Library Add. 72897: 289-306.

4. Thomason Tracts RAX E.840 \#14 E54 (15) Roxburghe Collection.

5. Wynne, Edward. The British India. British Library Collection 17: 262.

6. AHRB Research Centre for Textile Conservation \& Textile Studies Annual Conference (2004) Winchester, England, Scientific Analysis of Ancient and Historic Textiles.

7. Amphlett Hilda (1974) Hats: A History of Fashion in Headwear. Great Britain: The Garden City Press Ltd.

8. Androsko RJ (1971) Natural Dyes and Home Dyeing. Dover Publications, New York, USA.

9. Arnold Janet (1985) Patterns of Fashion: The Cut and Construction of Clothes for Men and Women. Macmillan Publishers Ltd., London, UK.

10. Arnold Janet (1988) Queen Elizabeth's Wardrobe Unlock'd. Leeds: W.S. Maney \& Son, London, UK.

11. Bain Allison (1997) Archaeoentomological Analysis at the Ferryland Site, Newfoundland. Unpublished Report, Ottawa, Canada.

12. Baines Patricia (1985) Flax and Linen. Aylesbury: Shire Publications, UK. 


\section{Global Journal of Archaeology \& Anthropology}

13. Beatty Michael (2003) The English Royal Family of America, from Jamestown to the American Revolution. McFarland \& Company, London, UK.

14. Beaudry, Mary C, Lauren J Cook, Stephen A Mrozowski (1991) Artifacts and Active Voices: Material Culture as Social Discourse. In: The Archaeology of Inequality. Randall HMc Guire, Robert Paynter (Eds.) England: Blackwell pp. 141-152.

15. Becker Vivienne (1982) Antique and 20 $0^{\text {th }}$ Century Jewellery. Von Nostrand Reinhold Co, New York, USA

16. Becker, Mary A, Polly Willman, Noreen C Tuross (1995) The U.S. First Ladies Gowns: A Biochemical Study of Silk Preservation". Journal of the American Institute for Conservation 34(2): 141-152.

17. Benson, Joel (2002) Changes and Expansion in the English Cloth Trade in the Seventeenth Century:: The Edwin Mellen Press, UK.

18. Berkley James (1969) The Literature of England. L.W. Singer Company Inc, New York, USA.

19. Berrie BH (1997) Prussian Blue. In: Artists' Pigments: A Handbook of Their History and Characteristics, Fitzhugh EW (Eds.), National Gallery of Art, Washington, USA, pp. 194-195.

20. Berry Helen (2003) Gender, Society and Print Culture in Late-Stuart England. Ashgate, England, UK.

21. Berry Paul (2002) The Numismatic Record of Ferryland". Avalon Chronicles 7 (2002): 1-71.

22. Booth John (1983) Looking at Old Prints. Wiltshire: Cambridge House Books, USA.

23. Bowles, Carver (1970) Catchpenny Prints. Dover Publications, New York, USA.

24. Bredif Josette (1989) Printed French Fabrics. Rizzoli International Publications, New York, USA.

25. Brunello F (1973) The Art of Dyeing in the History of Mankind. Neri Pozza (Eds.), New York, USA

26. Buck Anne (1996) Clothes and the Child. Holmes and Meier, New York, USA.

27. Burnham, Dorothy K. Warp and Weft. New York: Charles Scribner's Sons, 1980.

28. Caferro William (1996) The Silk Business of Tommaso Spinelli. Fifteenth-Century Florentine Merchant and Papal Banker. Renaissance Studies 10(4): 417-439.

29. Carter Matthew (1997) A Seventeenth-Century Smithy at Ferryland, Newfoundland. Avalon Chronicles 2: 73-106.

30. Cell Gillian T (1969) English Enterprise in Newfoundland. University of Toronto Press, Toronto, Canada.

31. Chapman Stanley (2002) Hosiery and Knitwear: Four Centuries of Small-Scale Industry in Britain. Oxford University Press, New York, USA.

32. Chenciner Robert (2000) Madder Red, A History of Luxury and Trade. Curzon Press, England, UK.

33. Comis Sandra Y (2003) Prehistoric Garments from the Netherlands. In: Textilienaus Archaologie und Geschichte. Neumünster: Wachholtz Verlag pp. 193-224

34. Corner David (1991) The Tyranny of Fashion: The Case of the FeltHatting Trade in the Late Seventeenth and Eighteenth Centuries. Textile History 22(2): 153-178.

35. Croft Pauline (1987) The Rise of the English Stocking Export Trade. Textile History 18(1): 3-16.

36. Crompton Amanda (2000) A Planter's House at Ferryland, Newfoundland. Avalon Chronicles 5: 1-48.
37. Cronyn JM (1990) The Elements of Archaeological Conservation Routledge, London, UK.

38. Crowfoot Elisabeth (1992) Frances Pritchard and Kay Staniland. Textiles and Clothing. HMSO, London, UK.

39. Cunnington C (1963) Willett and Phillis Cunnington. Handbook of English Costume in the Seventeenth Century. Faber and Faber, London, UK.

40.Cumming Valerie (1981) Exploring Costume History. Batsford Academic and Educational Ltd, London, UK.

41. Cumming Valerie (1982) Gloves. Drama Book Publishers, New York USA

42. Cumming Valerie (1984) A Visual History of Costume: The Seventeenth Century. Drama Book Publishers, New York, USA.

43. Davis Stephen (1997) Piecing Together the Past: Footwear and Other Artefacts from the Wreck of a $16^{\text {th }}$ century Spanish Basque Galleon. In: Artefacts from Wrecks: Dated Assemblages from the late Middle Ages to the Industrial Revolution. Mark Redknap, David Brown (Eds.), Oxford, UK.

44. Deagan Kathleen (2003) Colonial Origins and Colonial Transformations in Spanish America. Historical Archaeology 37(4): 3-14.

45. De Francesco Grete (1940) Silk Fabrics in Venetian Paintings. CIBA Review 29: 135-149.

46. De Winkel Marieke (1998) The Interpretation of Dress in Vermeer's Paintings. In: Vermeer Studies. Gashell I, Jonker M (Eds.), Yale University Press, New Haven, USA.

47. Doran Susan (2000) Elizabeth I and Foreign Policy. Routledge, London, UK.

48. Dubuc Elise (2002) Vétement, Corps, MuseeL'Objet - Subjet on le Patrimoine - Incarne. diss., Université de Montreal, USA.

49. Geoff Egan, Geoff Lead (1995) Cloth Seals and Related Items in the British Museum, ccasional. The British Museum, London, UK, p. 93

50. Ginsburg Madeleine (1984) Avril Hart and Valerie D. Mendes. Four Hundred Years of Fashion. V\&A Publications, London, UK.

51. Eirwen Jones Mary (1969) A History of Western Embroidery. WatsonGuptill Publications, New York, USA.

52. Eirwen Jones Mary (1974) English Crewel Designs. Macdonald, London, UK.

53. Emery Irene (1995) The Primary Structures of Fabrics: An Illustrated Classification. Watson-Guptill Publications, Washington, USA.

54. Epstein Diana, Millicent Safro (1991) Buttons. Harry Abrams Inc, New York, USA.

55. Fairholt FW (1976) Costume in England. EP Publishing, London, UK.

56. Farrell Jeremy (1992) Socks and Stockings. Batsford, London, UK.

57. Feltwell John (1990) The Story of Silk. Alan Sutton Publishing, Gloucestershire, UK.

58. Freist Dagmar (1997) Governed by Opinion: Politics, Religion and Dynamics of Communication in Stuart London. Tauris Academic Studies, New York, USA.

59. Findlay Marjory (1989) Four Black-Dyed Silk Textiles of the Late $17^{\text {th }}$ Century. Dyes in History and Archaeology 8: 36-38.

60. Frost Patricia (2000) Collecting Textiles. Octopus Publishing Group Ltd, Great Britain, USA.

61. Frugoni Chiara (2003) Books, Banks and Buttons and Other Inventions from the Middle Ages. Columbia University Press, New York, USA.

62. Gagnon Louise (1992) L’Apparition des Modes Enfantines au Quebec. Quebec: Institute Quebecois de Recherche sur la Culture, USA. 
63. Gaulton Barry (1997) Seventeenth-Century Stone Construction at Ferryland, Newfoundland (Area C). Avalon Chronicles 2: 1-42.

64. Gaulton Barry (1999) Seventeenth- and Eighteenth-Century Marked Clay Tobacco Pipes from Ferryland, Newfoundland. Avalon Chronicles 4: 25-56.

65. Gaulton Barry, Cathy Mathias (1998) Portuguese Terra Sigillata Earthenware Discovered at a $17^{\text {th }}$ Century Colonial Site in Ferryland, Newfoundland. Avalon Chronicles 3: 1-18.

66. Gaulton Barry, James A Tuck (2003) The Archaeology of Ferryland, Newfoundland. Avalon Chronicles 8: 189-224.

67. Garside Paul, Paul Wyeth (2003) Identification of Cellulosic Fibres by FTIR Spectroscopy- Thread and Single Fibre Analysis by Attenuated Total Reflectance. Studies in Conservation 48: 269-275.

68. Glassie Henry (1975) Folk Housing in Middle Virginia: A Structural Analysis of Historic Artifacts. University of Tennessee Press, Knoxville, USA.

69. Gilbert William (1996) Looking for Cupers Cove: Initial Archaeological Survey and Excavation at Cupids, Newfoundland. Avalon Chronicles 1: 67-95.

70. Grew Francis, Margrethe de Neergaard (1988) Shoes and Pattens. Her Majesty's Stationery Office, London, UK.

71. Ginsburg Madeleine, Avril Hart, Valerie D Mendes (1984) 400 Years of Fashion. Victoria and Albert Museum, London, UK.

72. Globe, Alexander Peter Stent (1985) London Print seller. Vancouver: University of British Columbia Press, USA.

73. Gohl EPG, Vilensky LD (1983) Textile Science: An Explanation of Fibre Properties. ( $2^{\text {nd }}$ edn), Longman Cheshire, Melbourne, Australias.

74. Goodway Martha (1987) Fiber Identification in Practice". Journal of the American Institute of Conservation 26(1): 27-44

75. Green Lorna R, Daniels VD (1990) Identification of Mordants Using Analytical Techniques". In: Dyes in History and Archaeology, No. 9, Proceedings of the Ninth Annual Meeting of the Association of Researchers into Dyes in History and Archaeology. Walton Rogers $\mathrm{P}$ (Eds.), New York, USA, p. 10-14.

76. Grew Francis, Margrethe de Neergaard (1988) Shoes and Pattens. HMSO, London, UK.

77. Griffiths Anthony (1998) The Print in Stuart Britain. British Museum Press, London, UK.

78. Gillard RD, Hardmand SM, Thomas RG, Watkinson DE (1994) The Detection of Dyes by FTIR Microscopy. Studies in Conservation 39(3): 187-192.

79. Hart Avril, Susan North (1998) Fashion in Detail: From the $17^{\text {th }}$ and $18^{\text {th }}$ Centuries. Rizzoli, New York, USA.

80. Harte NB (1790) The Rise of Protection and the English Linen Trade. In: Textile History and Economic History. Harte NB, Ponting KG (Es.), Manchester University Press, Manchester, England, UK, pp. 74-112.

81. Harte NB (1989) William Lee and the Invention of the Knitting Frame. In: Four Centuries of Machine Knitting, edited by John T. Millington and Stanley Chapman. Leicester, Knitting International, p. 17-18.

82. Heringa PK (1981) Soils of the Avalon Peninsula, Newfoundland. Newfoundland Research Branch.

83. Hill Erica (1995) Thimbles and Thimble Rings from the CircumCaribbean Region, 1500-1800: Chronology and Identification Historical Archaeology 29(1): 84-92.

84. Hind AM (1962) Engraving in England in the Sixteenth and Seventeenth Centuries: Part I the Tudor Period. Eds. Margery Corbett and M. Norton. Cambridge University Press, Cambridge, USA.
85. Hoeniger Cathleen (1995) The Renovation of Paintings in Tuscany. Cambridge University Press, Cambridge, USA.

86. Hollander Anne (1999) Feeding the Eye. Farrar, Straus and Giroux, New York, USA.

87. Hollander Anne (2002) Fabric of Vision: Dress and Drapery in Painting. National Gallery Company, London, UK.

88. Holme Randle (1688) Academy of Armory. Menson, Yorkshire, Scholar Press, England, UK.

89. Holmes Edwin F (1976) Thimbles. Gill and Macmillan, Dublin, Europe.

90. Holmes Edwin F (1985) A History of Thimbles. Cornwall Books, London, UK.

91. Horn Patrick, James A Tuck (1996) Archaeoparasitology at a 17th century colonial site in Newfoundland. Journal of Parasitology 82(3): 512-515.

92. Houart Victor (1977) Buttons: A Collector's Guide. Souvenir Press, London, UK.

93. Jakes Kathryn A, John C Mitchell (1992) The Recovery and Drying of Textiles from a Deep Ocean Historic Shipwreck. Journal of the American Institute for Conservation 31(3): 343-353.

94. Janowitz Meta (1988) Dutch Seventeenth-Century Genre Paintings and the Study of Foodways. Paper presented at the annual meeting of the Council for Northeast Historical Archaeology, St. Mary's City, Maryland, USA.

95. Janowitz Meta (1993) Indian Corn and Dutch Pots: SeventeenthCentury Foodways in New Amsterdam New York City". Historical Archaeology, New York, USA, 27(2): 6-24.

96. Jenkins Keith (2003) Refiguring History. Routledge, New York, USA.

97. Jensen Lars Vig Whalers's (1990) Whalers's clothing from a $17^{\text {th }}-18^{\text {th }}$ century cemetery at likneset, northwest Svalbard. Acta Borealia 7(2): 36-55.

98. Kelso WM, Bly Straube (2003) Jamestown Phoenix. Avalon Chronicles 8 (2003): 57-85.

99. Kerridge Eric (1985) Textile Manufactures in Early Modern England. Manchester University Press, Manchester, UK.

100. Kidd Kenneth E, Martha Ann Kidd (1970) A Classification System for Glass Beads for the Use of Field Archaeologists. Canadian Historic Sites: Occasional Papers in Archaeology and History, No. 1. Ottawa: Department of Indian Affairs and Northern Development.

101. Kietzman Mary Jo (2004) The Self-Fashioning of an Early Modern Englishwoman. Ashgate, Burlington, USA.

102. King Rosalie (1985) Textile Identification, Conservation and Preservation. Park Ridge, Noyes Publications, New Jersey, USA.

103. Kitson Frank (2004) Old Ironsides: The Military Biography of Oliver Cromwell. Weidenfeld \& Nicolson, London, UK.

104. Krugler John D (2001) George Calvert: Courtier, Colonizer, Capitalist, Catholic. Avalon Chronicles 6: 1-18.

105. Latham RC, Mathews W (1970) The Diary of Samuel Pepys. University of California Press, Los Angeles, USA.

106. Lamont William (1996) Puritanism and Historical Controversy. UCL Press, London, UK.

107. Laver James (2002) Costume and Fashion: A Concise History. Thames, Hudson (Eds.), London, UK.

108. Laslett P (1965) The World We Have Lost Methuen, London, UK.

109. Leene Jentina E (1972) Textiles. In: Textile Conservation. Jentina E Leene (Eds.), Butterworths, London, UK. 


\section{Global Journal of Archaeology \& Anthropology}

110. Lemire Beverly (1991) Fashion's Favourite: The Cotton Trade and the Consumer in Britain. Oxford University Press, New York, USA.

111. Lemire Beverly (2003) Domesticating the Exotic: Floral Culture and the East India Calico Trade with England, c. 1600-1800. Textile 1(1): 64-85

112. Lewin Menachem, Stephen B Sello (1983) Handbook of Fibre Science and Technology. Dekker M (Eds.), New York, USA.

113. Lewis May, Florence (1953) Silk Textiles of Spain: Eighth to Fifteenth Centuries. Hispanic Society of America, New York, USA

114. Lipson EA (1953) Short History of Wool and Its Manufacture. William Heinemann Ltd, London, UK.

115. Longerich HP, Jackson SE, Jenner JA, Friel JK, Chen Z, et al. (1993) Progress in the Determination of Trace Elements Using Solution Nebulization ICP-MS". Paper presented at the 1993 European Winter Conference on Plasma Spectrochemistry, Granada, Spain, p. 10-15.

116. Love Harold (1993) The Culture and Commerce of Texts. University of Massachusetts Press, USA.

117. Luijten Ger (1996) Frills and Furbelows: Satires on Fashion and Pride around 1600. Simiolus 25: 141-160.

118. Lunger Knopper Laura (1998) The Politics of Portraiture: Oliver Cromwell and the Plain Style. Renaissance Quarterly 51(4): 12821319.

119. Mann J de L (1971) The Cloth Industry in the West of England. Clarendon Press, Oxford, UK.

120. Mallios Seth (2005) Back to the Bowl: Using English Tobacco Pipebowls to Calculate Mean Site-Occupation Dates. Historic Archaeology 39(2): 89-104

121. Mathew David, James I (1967) Eyre and Spottiswoode, London, UK.

122. Mathias Cathy (1995) A Conservation Strategy for a Seventeenth Century Archaeological Site at Ferryland, Newfoundland. Journal of IIC-CG 19: 14-22.

123. Mathias Cathy (1995) Examination of Interactions Between Ferrous Metals and the Archaeological Burial Environment at a SeventeenthCentury Plantation Site MSc. Thesis, Memorial University of Newfoundland.

124. Mathias Cathy, Jerkic SM (1995) Investigating "WH": A Nineteenth Century Burial from L'Anse Au Loup, Labrador. Canadian Journal of Archaeology 19: 101-116.

125. Mathias Cathy, Matthew Carter, Barry Gaulton, Mike Tubrett (2003) Metallurgic Analysis of Slag Samples from a Seventeenth-Century Blacksmith Shop in Ferryland, Newfoundland. Material History Review 57: 67-72

126. Mathias Cathy (2004) Elizabeth Moffatt and Alison Murray, Technical Analysis of Textile Remains from a $17^{\text {th }}$-Century English Plantation at Ferryland, Newfoundland and Labrador, Canada. Journal of the Canadian Association for Conservation 29: 26-41.

127. Matthews Keith (1988) Lectures on the History of Newfoundland.

128. Merriman John (1996) A History of Modern Europe. Norton and Company, New York, USA

129. Miller Daniel (1987) Material Culture and Mass Consumption. B Blackwell, Oxford, UK.

130. Miller Henry M (2003) Lord Baltimore's Colony of Maryland and its Capital of St. Mary's City. Avalon Chronicles 8: 225-261.

131. Mills JS, White R (1994) The Organic Chemistry of Museum Objects. $2^{\text {nd }}$ edition. Butterworth-Heinemann, Oxford, UK.

132. Morris, Morgan James Reginald (1954) Examination of Three Brass Pins of $17^{\text {th }}$ Century Manufacture from Jamestown. Virginia: National Park Service, Colonial National Historical Park, USA.
133. Morshead, O.F., ed. (1960) Everybody's Pepys: The Diary of Samuel Pepys, 1660-1669.New York: Harcourt, Brace and Co.,

134. Moryson Fynes (1967) An Itinerary Latin. Shakespeare's Europe: A Survey of the Conditions of Europe at the End of the Sixteenth Century, Unpublished Chapters of Fynes Moryson's Itinerary, 1617. Charles Hughes (Eds.), $\left(2^{\text {nd }}\right.$ edn), Benjamin Blom, New York, USA.

135. Muthesuis Anna (1995) Studies in Byzantine and Islamic Silk Weaving. The Pindar Press, London, UK

136. Needles Howard L (1981) Handbook of Textile Fibers, Dyes and Finishes. Garland STPM Press, New York, USA.

137. Needles Howard L, Alger KW, Meyer RD, Schenter K, Kristinsdottir TE, et al. (1994) Degradation of Textile Fabrics Under Aerobic and Anaerobic Short-Term Soil Burial Conditions. American Association of Textile Chemists and Colorists. International Conference and Exhibition Book of Papers pp. 330-337.

138. Nixon Douglas (1999) A Seventeenth-Century Planter's House at Ferryland. Newfoundland Avalon Chronicles 4: 57-95.

139. Noël Hume Ivor (1969) A Guide to Artifacts of Colonial America. Random House, New York, USA

140. Nord Anders G, Kate Tronner (2000) A Note on the Analysis of Gilded Metal Embroidery Threads. Studies in Conservation 45: 274-279.

141. O'Connell Sheila (1999) The Popular Print in England. British Museum Press, London, UK.

142. Ordoñez Margaret T, Linda Welters (1998) Textiles from the Seventeenth-Century Privy at the Cross-Street Back Lot Site Historical Archaeology 32(3): 81-90.

143. Peacock Elizabeth E (1999) A Note on the Effect of Multiple Freezethaw Treatment on Natural Fibre Fabrics. Studies in Conservation 44(1): $12-18$

144. Peacock Primrose (1978) Discovering Old Buttons. Shire Publications, Aylesbury, UK.

145. Pepys Samuel (1970) In: The Diary of Samuel Pepys, 4, 1663. Latham RC, Matthews W (Eds.), University of California Press, Los Angeles, USA

146. Poni Carlo (1997) Fashion as Flexible Production: The Strategies of the Lyons Silk Merchants in the Eighteenth Century. In World of Possibilities. Charles F Sabel, Jonathan Zeillin (Eds.), Cambridge University Press, New York, USA, p. 37-74.

147. Ponting KG (1976) Indigo and Woad. Folk Life Studies 14(1): 75-88.

148. Panting KG (1978) Documents and Sources IX: In Search of William Lee. Textile History 9(1): 174-175.

149. Ponting KG (1979) Knitted Caps. Bulletin du Liaison du Centre International d'Etude des Textiles Ancients 49: 78-81.

150. Pope Peter E (1986) Ceramics from Seventeenth Century Ferryland. Newfoundland M.A. Thesis, Memoria University of Newfoundland, Canada.

151. Pope Peter E (1992) The South Avalon Planters, 1630 to 1700 Residence, Labour, Demand and Exchange in Seventeenth Century Newfoundland. diss., Memorial University of Newfoundland, Canada.

152. Pope Peter E (1993) Documents Relating to Ferryland 1597-1726, a Text base, Including Original Transcriptions. Report on file at the Colony of Avalon Foundation, Ferryland, Newfoundland, Canada.

153. Pope Peter E (1996) Six Letters from the Early Colony of Avalon. Avalon Chronicles 1: 1-20.

154. Pope Peter E (1997) The Many Landfalls of John Cabot. University of Toronto Press, Toronto, Canada.

155. Pope Peter E (1998) Baltimore vs. Kirke: Newfoundland Evidence in an Interregnum Lawsuit. Avalon Chronicles 3: 63-99. 


\section{Global Journal of Archaeology \& Anthropology}

156. Pope Peter E (2003) The English in Newfoundland in the Century after Cabot. Avalon Chronicles 8: 5-26.

157. Pope Peter E (2004) Fish into Wine: The Newfoundland Plantation in the Seventeenth Century. University of North Carolina Press, Chapel Hill, USA.

158. Potter M David, Bernard P Corbman (1967) Textiles: Fiber to Fabric. ( $4^{\text {th }}$ edn), McGraw-Hill, New York, USA.

159. Pratt Lucy, Linda Woolley (1999) Shoes. V \& A Publications, London, UK.

160. Pritchard Francis (2003) The New Draperies: Examples from Archaeological Deposits in England. In: Textilienaus Archäologie und Geschicte: Festschrift für Klaus Tidow. Banck J, Bender Jorgensen L, Rast-Eicher A (Eds.), Neumünster: Wachholtz Verlag pp. 222-232.

161. Priestley Ursula (1991) The Marketing of Norwich Stuffs. Textile History 22(2): 275-288.

162. Ribeiro Aileen (2006) Fashion and Fiction: Dress in Art and Literature in Stuart England. Yale University Press, New Haven, USA.

163. Salzman Paul (2002) Literary Culture in Jacobean England Reading. Palgrave Macmillan, New York, USA.

164. Scarisbrick Diana (1993) Rings: Symbols of Wealth, Power and Affection. Thames and Hudson, London, UK.

165. Schama Simon (2001) A History of Britain. Hyperion, New York, USA.

166. Shammas Carole (1993) Changes in English and Anglo-American consumption. In; Consumption and the World of Goods, John Brewer, Roy Porter (Eds.), Routledge, London, UK, pp. 177-205.

167. Shesgreen Sean (2002) Images of the Outcast: The Urban Poor in the Cries of London New Jersey: Rutgers University Press, UK

168. Smith Albert, Lillian, and Jane Ford Adams (1951) The Button Sampler. New York: Gramercy Publishing Company.

169. Spufford M (1984) The Great Reclothing of Rural England: Petty Chapmen and Their Wares in the Seventeenth Century. Hambledon Press, London, UK.

170. Steane John (1984) The Archaeology of Medieval England and Wales. University of Georgia Press, Athens, Greece.

171. Stoddart Eleanor (2000) Seventeenth-Century Tin-Glazed Earthenware from Ferryland. Avalon Chronicles 5: 49-99.

172. Strong Roy (1980) Charles I's Clothes for the years. Journal of Costume 14: 73-89.

173. Stroud Angus (1999) Stuart England. Routledge, London, UK.

174. Styles John (2000) Product Innovation in Early Modern London. In: Past and Present 168 (1): 124-169.

175. Swann June (1982) Shoes. Batsford BT, London, UK.

176. Swindlehurst Catherine (2001) An unruly and presumptuous rabble: the reaction of the Spital fields weaving community to the settlement of the Huguenots. In: From Strangers to Citizens: The Integration of Immigrant Communities in Britain, Ireland and Colonial America, 1550-1750. Eds. Randolph Vigne and Charles Littleton. Sussex Academic Press, Portland, USA.

177. Tarrant Naomi (1994) The Development of Costume. Routledge, London, UK

178. Temple Blair (2004) Somerset and Dorset Ceramics at SeventeenthCentury Ferryland, Newfoundland. MA Thesis, Memorial University of Newfoundland, Canada.

179. Terry WN (1981) Shoe Buckles - Northampton Museum Northamptonshire: Northampton Borough Council of Museums and Art Gallery, England.
180. Thirsk Joan (1973) The Fantastic Folly of Fashion: The English Stocking Knitting Industry 150. In: Textile History and Economic History: Essays in Honour of Julia de Lacy Mann. Edited by N.B. Harte, K.G. Ponting. Manchester University Press, Manchester, United Kingdom.

181. Thirsk Joan (1978) Economic Policy and Projects: The Development of a Consumer Society in Early Modern England. Clarendon Press, Oxford, UK.

182. Thirsk Joan (1998) Luxury Trades and Consumerism. In: Luxury Trades and Consumerism in Ancient Regime Paris: Studies in the History of the Skilled Workforce. Edited by Robert Fox and Anthony Turner. Ashgate Alder Sort, Great Britain, USA.

183. Timár-Balázsy, Agnes, Dinah Eastop (1999) Chemical Principles of Textile Conservation. Butterworth, Oxford, UK.

184. Trautman, Patricia (1989) Dress in Seventeenth-Century Cambridge, Massachusetts: An Inventory-Based Reconstruction. In: Early American Probate Inventories, ed. Peter Benes, Dublin Seminar for New England Folklife Annual Proceedings, Boston University Scholarly Publications, Boston, USA, p. 51-71.

185. Tuck James A, Robert Grenier (1981) A $16^{\text {th }}$-Century Basque Whaling Station in Labrador. Scientific America pp. 180-190.

186. Tuck James A (1987) The World's First Oil Boom. Archaeology 40: 50-55.

187. Tuck James A, Robert Grenier, Red Bay (1989) Labrador World Whaling Capital. St.John's: Atlantic Archaeology Ltd.

188. Tuck James A (1993) Archaeology at Ferryland, Newfoundland. Newfoundland Studies 9(2): 293-310.

189. Tuck James A (1996) Archaeology at Ferryland, Newfoundland. Avalon Chronicles 1: 21-41

190. Tuck James A, Barry Gaulton (2001) Archaeology at Ferryland 19982000. Avalon Chronicles 6: 89-106.

191. Vander Kiste, John William (2003) Mary United Kingdom: Sutton Publishing. United Kingdom.

192. Vons-Comis, Sandra Y (1987) Workman's Clothing or Burial Garments? Seventeenth and Eighteenth-Century Clothing Remains from Spitsbergen". In Norsk Polarinstitutt Rapportserie, Smeerenburg Seminar, Oslo, Norway, pp. 79-107.

193. Vons-Comis, SandraY (1988) Kleren Maken de Man: Zeventiende-en Achttiende-eeuwse Kleding van Spitsbergen. In: Walvisvaart in de Gouden Eeuw: Opgraving op Spitsbergen, Amsterdam: De Bataafsche Leeuw pp. 97-119.

194. Walton P (1981) The Textiles, In: An Excavation in the Castle Ditch, Newcastle upon Tyne. Archaeologia Aeliana 9: 194-196.

195. Walton P, Taylor G (1991) The Characterization of Dyes in Textiles from Archaeological Excavations. Chromatography and Analysis $\mathrm{p}$. $5-7$.

196. Wardle Patricia (2000) 75 X Lace. Waanders Publishers, Amsterdam, Europe.

197. Wardwell Anne E (1976) The Stylistic Development of 14th-and 15th-Century Italian Silk Design. Aachener Kunstblätter des Museumvereins 47: 177-226.

198. Wardwell Anne E (1987) Flight of the Phoenix: Crosscurrents in Late Thirteenth and Fourteenth-Century Silk Patterns and Motifs. The Bulletin of The Cleveland Museum of Art 74: 2-35.

199. Watt James CY, Anne E Wardwell (1997) When Silk was Gold: Central Asian and Chinese Textiles. Metropolitan Museum of Art, New York, USA.

200. Watt Tessa (1991) Cheap Print and Popular Piet. Cambridge University Press, Cambridge, USA 
201. Waugh Norah (1988) The Cut of Men's Clothes. Faber and Faber, London, UK.

202. Weatherill Lorna (1993) The Meaning of Consumer Behaviour in the Late Seventeenth- and Early Eighteenth-century England. In: Consumption and the World of Goods, Eds. John Brewer and Roy Porter, Routledge, London, UK, pp. 206-226.

203. Wheale Nigel (1999) Writing and Society: Literacy, Print and Politics in Britain. Routledge, London, UK.

204. White, Carolyn L (2004) What the Warners Wore: An Archaeological Investigation of Visual Appearance. Northeast Historical Archaeology 33: 39-66.

205. Whitehead Ross (1996) Buckles. Chelsmford, Greenlight Publishing, Essex, UK.

206. Wilson Derek (2003) All the King's Women. Hutchinson, London, UK.

207. Wincott Heckett, Elizabeth (2003) Connections to a Troubled Time: recently excavated sixteenth and seventeenth century textiles from Ireland. In: Textilienaus Archaologie und Geschichte. Neumünster Wachholtz Verlag pp. 224-233.

208. Wouters J (1985) High Performance Liquid Chromatography of Anthraquinones: Analysis of Plant and Insect Extracts and Dyed Textiles. Studies in Conservation 30(3): 119-128.

209. Zainer Claudio (1994) Current Historical Research into the Silk Industry in Italy. Textile History 25: 61-78.

210. Chromium Compounds (1993) In: Kirk Othmer Encyclopedia of Chemical Technology, Fourth Edition, John Wiley and Sons, New York, USA, 6: 263.

211. The History of the Kings and Queens of England and Scotland (2003) Armadillo Books, England, UK.

212. Timár-Balázsy, Agnes, Dinah Eastop (1998) Chemical Principles of Textile Conservation. Butterworth-Heinemann, Oxford, UK.

213. Berry Paul (2005) Chief Curator, National Currency Collection, Bank of Canada.

214. Burnham Dorothy (2001) Former Curator of Textiles, Royal Ontario Museum, Canada.

215. de Winkel Marieke (2001) Art Historian, Rembrandt Research Project. Amsterdam, Europe.

216. de Witt David (2006) Art Historian, Bader Curator of European Art Agnes Etherington Art Centre, Kingston, Ontario, Canada.

217. Dicks, Robert (2003) Gemologist (GIA), Marquise Appraisals, St John's, NL, Canada.

218. Gilbert, Bill. Head Archaeologist, Cupids Archaeology Project, 2003.

219. Greiff, Susanne. Textile Researcher, Personal Communication, AHRB Research Centre for Textile Conservation \& Textile Studies Annua
Conference, 13-15 July 2004, Winchester, England, Scientific Analysis of Ancient and Historic Textiles.

220. Hacke Marie (2004) Textile Reseacher, Winchester Textile Conference.

221. Hayward Mary (2004) Head of Studies and Research, AHRB Research Centre for Textile Conservation and Textile Studies, Wincheste.

222. Hodgett Lisa (2005) Department of Anthropology, University of Western Ontario, Canada.

223. Lemire Beverly (2004) University of New Brunswick, New Brunswick, USA.

224. Logan, Judy (2001) Senior Conservator, Canadian Conservation Institute, Ottawa, Canada.

225. Miller Aaron (2004) MA graduate, Memorial University of Newfoundland, Canada.

226. Newton Charlotte (2004) Senior Conservator, Canadian Conservation Institute, Ottawa, Canada.

227. Pocius Jerry (2004) Memorial University of Newfoundland, Canada.

228. Pope Peter E (2002) Archaeology Unit, Memorial University of Newfoundland, Canada.

229. Pritchard Francis (2003) Textile Researcher, Whitworth Art Gallery, University of Manchester, England, UK.

230. Renouf Priscilla (2003) Archaeology Unit, Memorial University of Newfoundland, Canada.

231. Skals Irene (2004) Textile Conservator, National Museum of Denmark, Europe.

232. Straube, Bly. Curator (2004) Jamestown Rediscovery, Virginia, United States.

233. Temple, Blair (2004) Researcher and Contract Archaeologist, St. John's, Newfoundland, Canada.

234. Tuck James A (2004) Professor Emeritus, Archaeology Unit, Memorial University of Newfoundland, Canada.

235. Vons-Comis SandraY (2001) Textile Researcher, Amsterdam, Netherlands, Europe.

236. Whitridge Peter (2003) Archaeology Unit, Memorial University of Newfoundland, Canada.

237. Wouters (2004) Laboratory for Materials and Techniques, Royal Institute for Cultural Heritage, Brussels, Belgium, Europe.

238. Wright Tom (1997) Goldsmith and Silversmith of Trepassy, Newfoundland, Canada. 
This work is licensed under Creative Commons Attribution 4.0 License DOI: 10.19080/GJAA.2018.05.555675
Your next submission with Juniper Publishers will reach you the below assets

- Quality Editorial service

- Swift Peer Review

- Reprints availability

- E-prints Service

- Manuscript Podcast for convenient understanding

- Global attainment for your research

- Manuscript accessibility in different formats ( Pdf, E-pub, Full Text, Audio)

- Unceasing customer service

Track the below URL for one-step submission https://juniperpublishers.com/online-submission.php 